\title{
Benefits for Child Care Workers: How the State Could Help through a Medicaid Waiver
}

\author{
Amanda M. McDougald Scott, Clemson University
}

\begin{abstract}
Child care is expensive, and many parents struggle to afford care; furthermore, even though child care costs are high, child care providers in the United States (US) are not making a living wage. Child care professionals (ages 0-5 in child care homes or centers) earn less income than Kindergarten teachers, pre$\mathrm{K}$ teachers, non-farm animal caretakers, and the US estimate of all workers' annual median salary (Bureau of Labor Statistics, 2020a, 2020b). Workers in comparable professions are also usually offered benefits for their labor, which child care professionals are not (Kwon, 2019; National Survey of Early Care and Education Project Team, 2020; Otten et al., 2019; Whitebook, McLean, Austin, \& Edwards, 2018). This often necessitates use of public assistance. Because many child care workers are not provided access to health insurance or other health-related benefits through their employers, they must seek access to health care in other ways. Additionally, turnover rates among child care workers are high, and wages and benefits are a large part of the reason why child care professionals leave their jobs (McDougald Scott, 2021a). This policy analysis (a) reviewed the current struggle (as of May 2021) that child care workers in the United States (in general) and South Carolina (in particular) experience compared with employees in other fields; and (b) explore options (particularly a Medicaid waiver option) that might improve the situation. South Carolina (SC) is one of the 13 states that have not expanded Medicaid; most of the 13 states are in Southern United States (US) region, which makes an extrapolation of SC research reasonable. Lessons learned from SC childcare data should reflect closely what may be found in other non-expansion states, but research from the literature review will not be SC-specific. Relevant peer-reviewed, government documents, state and national data, and grey literature were reviewed and analyzed. There have been ongoing efforts (although insufficient even in more successful efforts) with mixed results to improve the pay for child care workers for decades. Progress for earning a living wage will require a systems overhaul for early education, but child care providers cannot wait for workforce environmental improvements. Action must be taken now to augment the shortage of healthcare access for child care providers. In SC, Medicaid helps some child care workers receive access to health care, but expansion through Medicaid waiver 1115 would include many more child care workers who do not currently have access.
\end{abstract}

\section{Keywords}

Childcare workers, child care, Medicaid, health insurance, health care, low-income workers

Child care is expensive, and many parents struggle to afford care; moreover, even though child care costs are high, child care providers in the United States (US) are not making a living wage (Bureau of Labor Statistics, 2020a; Economic Policy Institute, 2019; Glasmeier, 2021; Whitebook, Phillips, \& Howes, 2014). Child care worker pay improvement has been an issue that child care advocates have been working on for decades, producing mixed results, and often the complex structure of the child care system is cited as the reason for inability to improve pay (Whitebook et al., 2018; Whitebook et al., 2014). High child 
care provider turnover rates (estimated at $13 \%$ in 2012), which negatively impact the quality of care and are hard on children and families, are mostly attributed to low wages (Institute of Medicine \& National Research Council, 2015; S. Thomason et al., 2018; Whitebook et al., 2018). Therefore, the confluence of low wages for child care workers and inability to improve wages creates a societal problem for both the workforce who utilizes child care and those who provide caregiving services. As an economic imperative (Gould, Austin, \& Whitebook, 2017; McDougald Scott, 2018), something must be done to improve the financial and environmental situation for child care providers. If wages cannot be improved within the current system, it is time to look for another solution.

Women's - especially women of color's — work has been historically undervalued and underpaid, with a particular misperception of child caregiving labor as being unskilled and of little value (McLean, Austin, Whitebook, \& Olson, 2021; Michel, 1999; Smith, 2004). Women in Western culture (including the US) have been assigned the role of caregivers for children for decades, with the predominant view that only women with less money and resources have to work for money (Michel, 1999). In more conservative areas of the country, such as in the Southern US, maintenance of this view seems to be more prevalent. Therefore, paid caregiving work has also been seen as less desirable. For example, McDougald Scott (2021a) found that child care professionals felt that their communities and society treated them as if they were of a 'lower class' in society or seen as a 'servant.' As many of the women who have historically done caregiving work have not been formally educated in caregiving, it leads to the assumption that child care work is not skilled, and primarily consists of 'babysitting.'

Child care as a resource and service, as well as policy surrounding child care, has long been fraught with concern about (a) what a woman's duty and role is with regards to children (b) who child care is serving and why (Michel, 1999). During the Progressive and the New Deal eras of the United States, social assistance became available for many populations (low income, mentally ill, orphans, elderly, disabled), but no provisions were made for child care (Michel, 1999). Interestingly, it is seen as the government's responsibility to furnish public education for all, but providing quality child care for working parents has not been seen as equally important, regardless of the fact that the early years are the most important foundational years for brain growth (Michel, 1999; Zhao, Xu, \& He, 2019). Furthermore, child care should be seen as an economic imperative, for children, families, and employers as McDougald Scott (2018) outlines. ${ }^{1}$

Throughout the twentieth and into the twenty-first century, there has been a push for child care to be available for mothers (historically speaking) so that they will not be dependent on the government for income, yet the cost of child care itself is a burden on families (Malik, 2019; Michel, 1999). The burden of cost on families is essentially subsidized by the low wages paid to the workforce (Malik, 2019).

Due to the insufficient, unreliable, or unsuccessful efforts to increase the base pay for child care workers, as well as a resistance to or inability of child care owners to provide benefits to employees, a renewed examination is needed of ways to influence policy makers to implement change. One strategy is to focus on qualitative studies of lived experiences of child care workers dealing with low wages and lack of access to benefits and the extent to which such stories have been shared with policy makers in order to convince them to take action on improvement in the early childhood workforce environment (which includes pay and benefits).

\footnotetext{
${ }^{1}$ https://www.instituteforchildsuccess.org/child-care-an-economic-imperative-for-greenville/
} 
Even though there are both long- and short-term solutions to ameliorate the problem of low wages and no benefits enumerated in several sources, in many cases, it has been tough to gain traction for action through federal and state legislative bodies. This policy analysis expands upon some of the short-term solutions that have been offered, and continue to be necessary for policy and systems change. More long-term solutions for problems faced by the child care workforce would require an overhaul of the early childhood education and care system.

To understand the issue of how low wages and lack of benefits affects child care workers, this policy analysis reviewed the current (as of early 2021) struggle that child care workers in the US (in general) and SC (in particular) experience compared with employees in other fields. Options that might improve the situation (particularly a Medicaid waiver option) were also explored. An analysis of current and past solutions was reviewed, and recommendations for future action are offered.

This policy analysis (a) reviewed the current struggle that child care workers in the US (in general) and SC (in particular) experience compared with employees in other fields; (b) explored options (particularly Medicaid expansion options) that might improve the situation. South Carolina is one of the 12 states that has not expanded Medicaid; most of the 12 states are in Southern US region, which makes an extrapolation of SC research reasonable. Lessons learned from SC childcare data should reflect closely what may be found in other non-expansion states, but research was not limited to SC.

\section{A Note on Terminology}

Child care workers should be seen and respected as the invaluable people that they are, and sometimes the term 'workers' sounds too impersonal to adequately convey the emotional labor and bonding with children and families that is required of and provided by these professionals. For the purposes of this article, the terms 'child care worker,' 'child care provider,' 'child care teaching staff,' or 'early childhood educators' are used somewhat interchangeably. Distinctions between child care workers and pre-K or Kindergarten teachers (who are all early childhood educators) will be made as needed. Also as appropriate, distinctions may be made between teachers, directors, or administrative staff.

\section{Financial Challenges Facing Child Care Providers}

Child care workers are paid low wages (or no wages in the cases of many stay-at-home parents or other relative caregivers) (McDougald Scott, 2018; McDougald Scott, Rusnak, \& Carolan, 2019; Paschall, 2019). Nationally, the confluence of low wages relative to other fields and a frequent lack of benefits for child care providers create stress on this workforce. South Carolina child care workers make a median annual salary of $\$ 19,480$ (Bureau of Labor Statistics, 2020b); compared to the average US child care worker, who makes $\$ 24,230$ (Bureau of Labor Statistics, 2020c). Both of these salaries are less than $138 \%$ of the federal poverty level (FPL) (\$24,040 for a family of two, $\$ 36,570$ for a family of four) (U.S. Department of Health \& Human Services, 2021). Keeping child care workers in the workforce is an important component of sustaining the US economy (Economic Policy Institute, 2016; McDougald Scott, 2018; O’Donnell, 2015), and given the professional training expected and required in order to do the job well, these low wages are not doing much to retain them. 


\section{Education}

Nationwide, educational requirements vary according to the type of child care facility by which a child care worker is employed, age of children served, and the state in which a child care worker is employed (Whitebook et al., 2018). Professional recommendations based on extensive research by the Institute of Medicine and National Research Council (2015) indicate that lead caregivers or teachers for all ages birth through eight years should attain a minimum of a bachelor's degree, but the emphasis should be on knowledge and competencies relevant to working in the early childhood field. The National Institute for Early Education Research (NIEER) also recommends a minimum of a bachelor's degree for lead pre-K teachers, and specifies a minimum of a Child Development Associate (CDA) degree as a quality benchmark for pre-K assistants (Friedman-Krauss et al., 2019).

These qualifications require higher education and training, which can lead to student loan debt. One study of child care workers reported that of the $42 \%$ of the child care teaching staff sample who owed student debt, $52 \%$ owed $\$ 25,000$ or more; of the child care directors in the same sample, $32 \%$ reported having student loan debt, of which $64 \%$ owed $\$ 50,000$ or more (Whitebook et al., 2018). Student debt was more closely associated with employees having attained a bachelor's degree or higher: $74 \%$ of teaching staff and $95 \%$ of directors reported having student debt (Whitebook et al., 2018). As for training, best practices for child care workers encourage continuing education or professional development for child care workers and pre-K teachers, which requires time off work and tuition for the coursework (Institute of Medicine \& National Research Council, 2015; Whitebook et al., 2018). All of this adds to the financial stress of child care workers.

Due to varying requirements and complex systems, there are not always clear expectations or pay scales that inform child care providers what income they can expect, and there is variation between child care providers based on age, even when providers have the same credentials (Institute of Medicine, 2012; Institute of Medicine \& National Research Council, 2015; Russell, Lyons, \& Lowman, 2001; Whitebook et al., 2018). Reports indicate that providers with higher education attainment are assigned to care for older children, while younger children are assigned providers with lower educational attainment (see Figure 1) (National Survey of Early Care and Education Project Team, 2020; Rao \& Chen, 2018). Caregivers who only work with infants and toddlers generally make less than those who only work with children ages three to five — even when they hold the same credentials (Rao \& Chen, 2018).

Variation in pay according to the age of the child may be due to assumptions that younger children do not require the same level of expertise as older children, but infant and toddler caretakers need the same level of skill and education as preschool caretakers, and specialized child development training is necessary to obtain quality early childhood outcomes (Institute of Medicine \& National Research Council, 2015; Whitebook et al., 2018). Further, providers who are making less pay may also have lower educational attainment, but they are required to have the same skills as their co-workers with higher educational attainment (Rao \& Chen, 2018; Whitebook et al., 2018; Whitebook et al., 2014). This pay disparity according to the age of the child is a disservice not only to the child care providers, but the children and families they serve. Evidence has shown that cognitive development of children from 20 weeks gestation until age 2 years is critical to functioning later in life (Zhao et al., 2019). This suggests that specialized, and maybe more training and expertise should be required of child care professionals who work with the youngest children — and they should be compensated for this appropriately. 
The minimum South Carolina Department of Social Services (DSS) licensing requirement for child care providers (centers, faith-based, or family child care home) is that their teachers have obtained a high school diploma or GED, as well as six months working as a teacher or caregiver in a licensed or approved child care facility (Rao \& Chen, 2018). Lead pre-K teachers in SC are required to have a minimum of an associate degree, although a bachelor's degree is preferred (Friedman-Krauss et al., 2019). Ideally, to teach or care for the same age range of children, everyone should have the same educational requirements. Given that this is not currently the case, creating pay scales for child care, including pre-K, should reward education and years of experience - regardless of the age of the child taught.

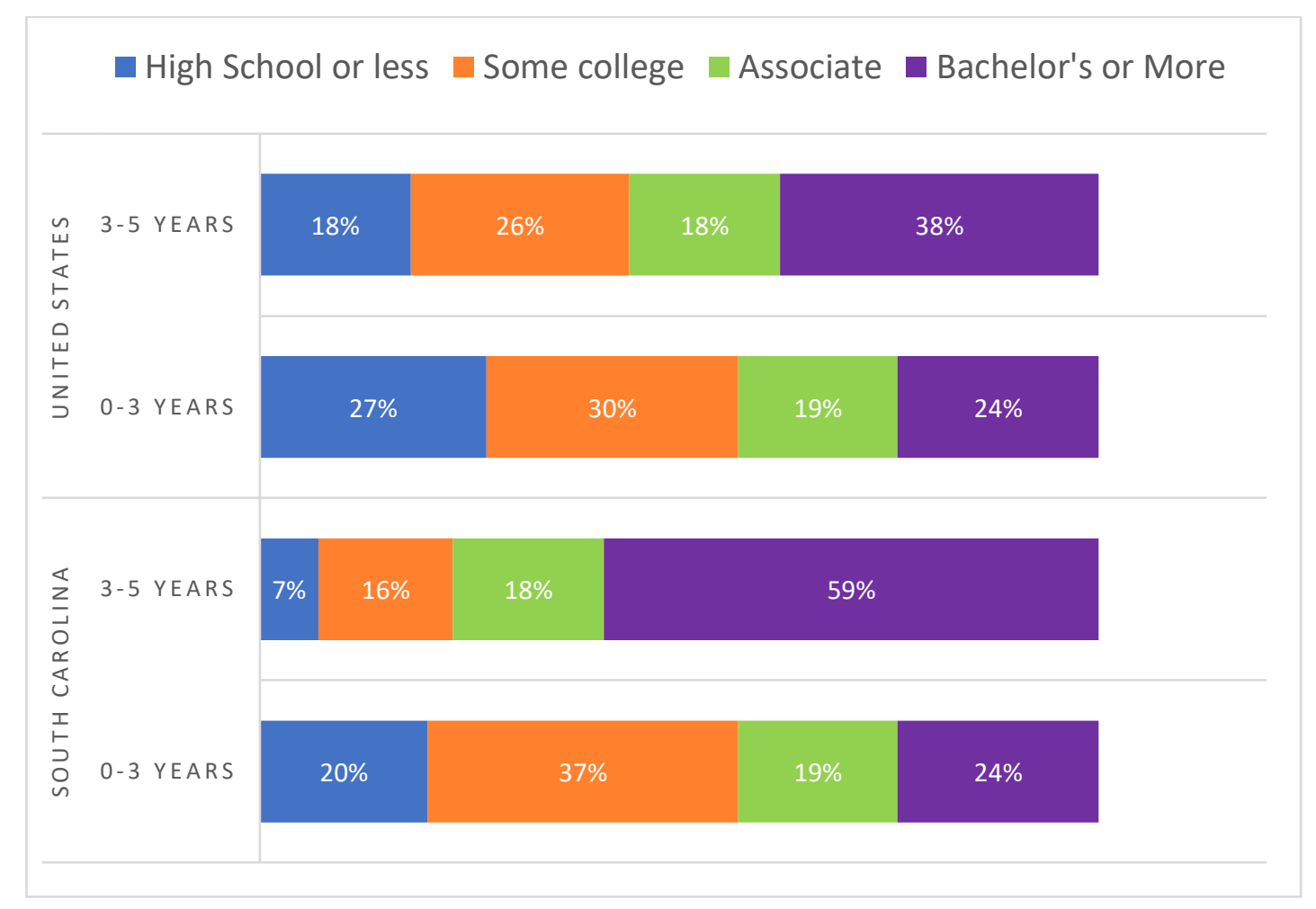

Figure 1. Child Care provider education attainment by age of children served. SC data from South Carolina Department of Social Services, Rao and Chen (2018), US data from National Survey of Early Care and Education Project Team (2020).

\section{Disparity between Similar Professions}

Child care workers (ages 0-5 in child care homes or centers) earn less income than Kindergarten teachers, pre-K teachers, non-farm animal caretakers, and the US estimate of all workers' annual median salary, as shown in Figure 2 (Bureau of Labor Statistics, 2020a, 2020b).

Pre-K, Kindergarten, and child care teaching staff for children between the ages of three to five years should have similar educational requirements and expectations, although as previously stated, these requirements and expectations vary by state. Almost half of US states (23) require at least a bachelor's degree for pre-K lead teachers (Whitebook et al., 2018). Because pre-K has varying availability between 
states, in places where pre- $\mathrm{K}$ is not available in the school system, child care centers or homes may provide care and instruction for the same age group. Although this is the case, as Figure 2 indicates, pre-K teachers are often paid more than child care workers. Pre-K teachers and similarly-credentialed child care workers caring for the same age children should be paid at the same level.

Kindergarten teachers nationwide are required to have a bachelor's degree; depending upon the state in which they teach, some Kindergarten teachers are required to obtain a teaching certificate (Bureau of Labor Statistics, 2019c; Teacher.org, 2019). As the data in Figure 2 indicate, pre-K teachers in SC earn an annual median wage of $\$ 22,990$, which is more than child care workers $(\$ 19,480)$ and far less than Kindergarten teachers $(\$ 53,770)$. Pre-K teachers in both child care and school settings consistently earn less money than Kindergarten teachers, even though best practices dictate, and many states require, that lead pre-K teachers hold bachelor's degrees (Friedman-Krauss et al., 2019).

Non-farm animal caretakers' charges involve a vulnerable population that needs to be cleaned up after, entertained, trained, fed, and kept safe much like young children; thus, this population is useful for wage comparison. Calculated using annual median incomes, non-farm animal caregivers in SC make about $\$ 2,630$ more than child care providers, and in the US the difference is $\$ 550$ (Bureau of Labor Statistics, 2020a, 2020b). Although the median income for non-farm animal caregivers is not estimated to be much more than child care providers, non-farm animal caregivers both in SC and the US make more.

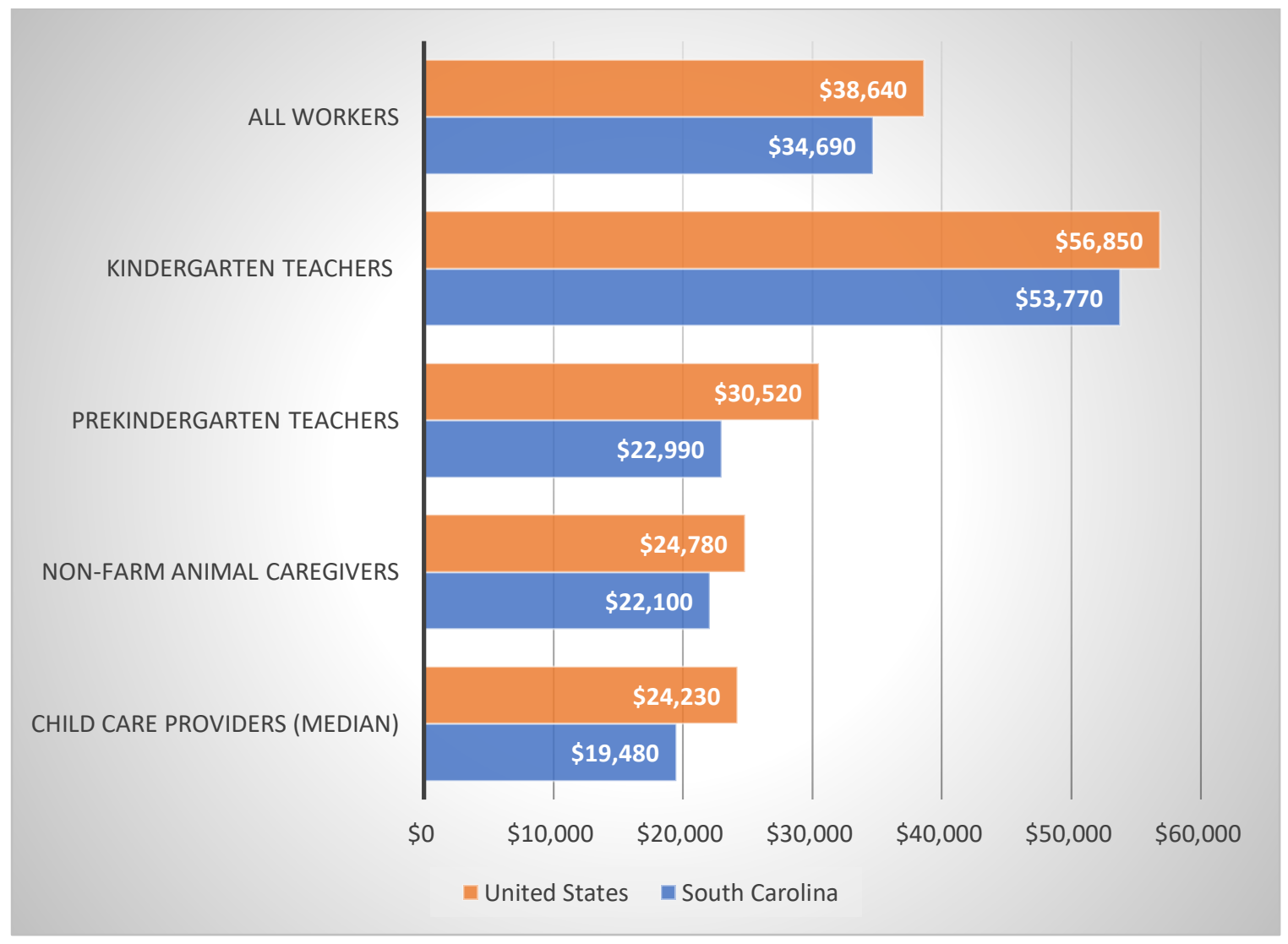


Figure 2. Median incomes for child care providers versus comparable occupations. SC data from Bureau of Labor Statistics (2020b); US data from Bureau of Labor Statistics (2020a).

Taking into account the history and political development of child care mentioned above, it should not be surprising that child care workers make less money than comparable professions. Women's work, especially the work of women of color, is under-paid and under-valued (McLean et al., 2021; Michel, 1999; Smith, 2004). Pre-K and Kindergarten teachers work for the school system, which is generally accepted as a right to which all children in the US are entitled, while child care is not seen in the same way (Michel, 1999). Child care workers who have earned bachelors' degrees may go into the early childhood education field and discover that they will make more money, and also earn benefits, by leaving child care and working in the school system (McDougald Scott, 2021a; Whitebook \& Sakai, 2003). This does not bode well for the children served by child care or the quality of child care as a whole.

\section{Public Assistance}

Another difference between child care providers and comparable workers is that child care providers are usually offered no benefits for their labor (Kwon, 2019; National Survey of Early Care and Education Project Team, 2020; Otten et al., 2019; Whitebook et al., 2018), which often necessitates use of public assistance. Over a period from 2014 to 2016, 53\% of child care workers in the US utilized one of four major public support and health care programs: the Federal Earned Income Tax Credit (EITC); Medicaid and the Children's Health Insurance Program (CHIP); Supplemental Nutrition Assistance Program (SNAP); and Temporary Assistance for Needy Families (TANF) (Whitebook et al., 2018). Compared to $21 \%$ of the US workforce overall accessing public assistance, the utilization rate of a single sector of the workforce - child care providers-is stark (Whitebook et al., 2018). Furthermore, research from the Center for the Study of Child Care Employment (CSCCE) shows an increase in child care providers' public assistance utilization rates from previous years as a result of expanded Medicaid eligibility in many states (Whitebook et al., 2018). The CSCEE identified Medicaid expansion as a strategy which particularly benefits early childhood providers; since Medicaid was expanded in 33 states, about one-third of child care workers and their families access health insurance through Medicaid (Whitebook et al., 2018).

\section{Insurance}

The 2018 SC Department of Social Services (DSS) child care workforce study sample indicated that only about $28 \%$ of child care workers were covered by private health insurance provided from their employer or workplace (see Figure 3) (Rao \& Chen, 2018). Twenty-eight percent of the DSS study sample did not answer the health insurance question, and are not included in Figure 3 or the following calculations (Rao \& Chen, 2018). 


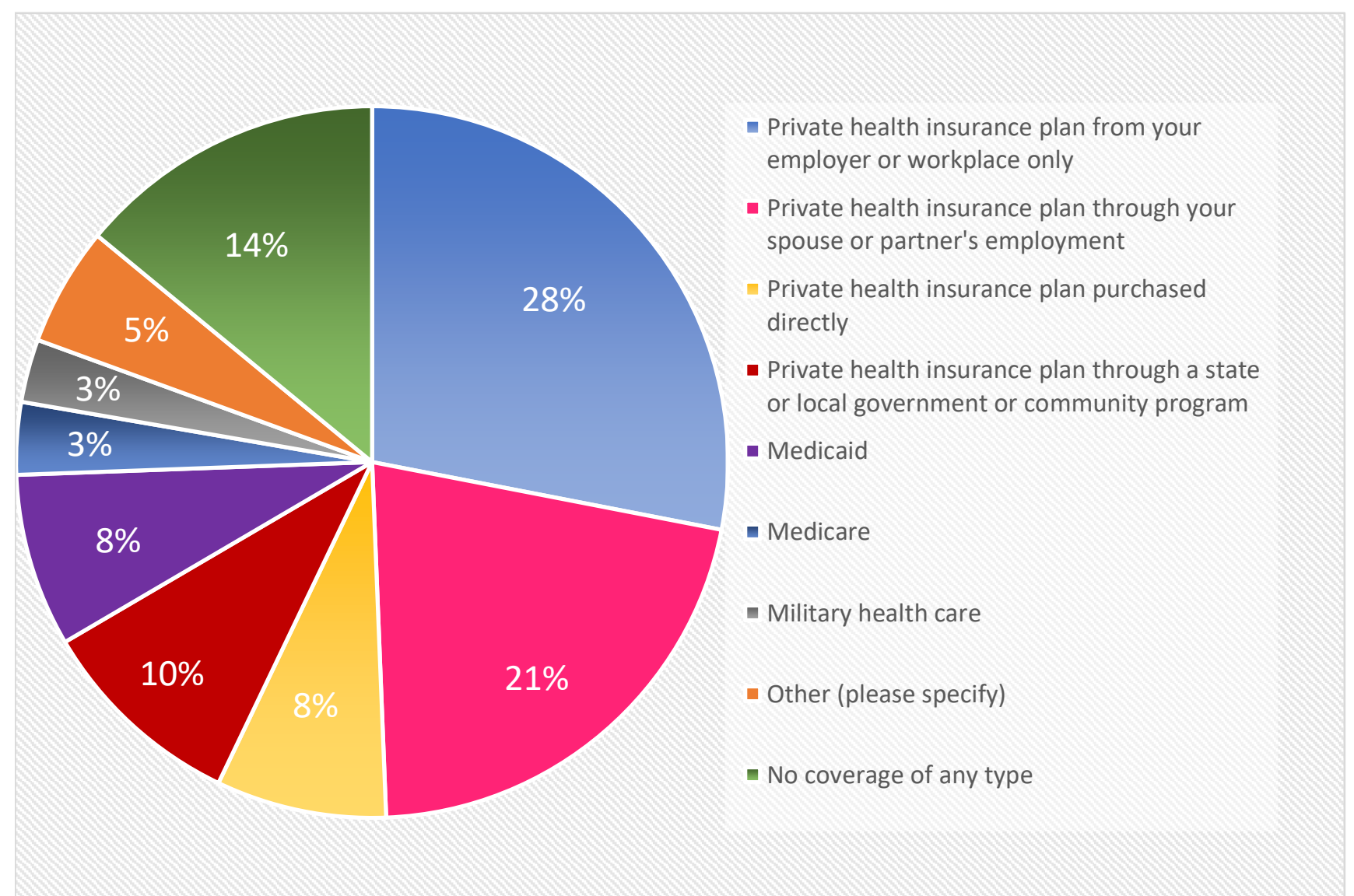

Figure 3. South Carolina insurance coverage status for child care providers. Data from (Rao \& Chen, 2018).

The remaining child care providers were responsible for either being on their spouse's health insurance (21\%), purchasing their own health insurance (8\%), or being un-insured (14\%) (Rao \& Chen, 2018); those who are un- or under-insured must pay for health care out of their own pockets, that creates additional pecuniary hardship. South Carolina is not a Medicaid expansion state, but if the $14 \%$ of caregivers who do not have coverage of any type were added to the $8 \%$ of child care workers currently enrolled in Medicaid, that would mean that at least $22 \%$ of workers could be covered.

Preliminary data for the US child care workforce from the National Survey of Early Care and Education (NSECE) study indicates that $16 \%$ of child care workers did not have health care coverage of any type (National Survey of Early Care and Education Project Team, 2020). Child care workers who were able to secure health insurance obtained it through their partner or spouse (24.5\%), enrolled in a healthcare exchange (5.5\%), directly with a health insurance company (1.3\%), high-deductible plans through their employers (13.8\%), Medicaid (15.7\%), Medicare (5.9\%), or military-related sources (12.4\%) (National Survey of Early Care and Education Project Team, 2020). Of the small number of child care workers who are offered paid sick leave, many are afraid to take it (Kwon, 2019; National Survey of Early Care and 
Education Project Team (National Opinion Research Center), 2012; Otten et al., 2019; Whitebook et al., 2018). This means that at least $31.8 \%$ of our child care workers across the country do not have adequate access to healthcare (National Survey of Early Care and Education Project Team, 2020).

\section{Health}

Health is an essential component to maintaining the workforce. For decades, researchers have indicated that workforce quality translates to caregiving quality (Institute of Medicine, 2012; Otten et al., 2019; Russell et al., 2001; Whitebook et al., 2018; Whitebook et al., 2014). Recent studies have shown that early childhood workers, including child care givers, suffer poorer mental and physical health outcomes than women of similar socioeconomic standing in other professions (or women who do not work) (Linnan et al., 2017; Otten et al., 2019; Whitaker, Becker, Herman, \& Gooze, 2013).

The Otten et al. (2019) mixed method study of early childhood education (ECE) workers reported evidence of poor health in both physical and mental capacities among this population. For example, food insecurity was found in $42 \%$ of the sample, compared to US food insecurity rates of $11.8 \%$ (Otten et al., 2019). Societal stress was also reported, as child care workers felt that parents and society as a whole does not respect them or their profession (Otten et al., 2019). Further, even in centers where child care providers were afforded sick leave, they reported feeling that they were unable to take advantage of sick leave due to short staffing (Otten et al., 2019). These factors perhaps help explain the study's finding that this sample reported depression scores that were double the US prevalence for women in similar income brackets (Otten et al., 2019). All of these factors contribute to an overall low morale, including poor physical and mental health.

Providing benefits for child care workers would be a great step forward in making them feel more appreciated and well-compensated. In addition, those within child care workers' care and co-workers would also benefit from not being exposed to illness brought in by workers who cannot take time off or access healthcare. Benefits that would help improve physical and mental health could include paid sick leave, pools of substitutes so that workers can take paid leave, and health insurance. The state of SC (as well as other non-expansion states) could start working towards improving the workforce environment and quality of child care overall by expanding Medicaid or using a Medicaid waiver for child care workers.

\section{Medicaid Expansion}

Medicaid expansion is a policy that increases healthcare coverage for individuals who are at the $138 \%$ federal poverty level (FPL) (or higher for some populations) instead of the 2013 rate of $61 \%$ FPL (Henry J. Kaiser Family Foundation, 2015). As of February 4, 2021, 39 states (including DC) have expanded Medicaid (Kaiser Family Foundation, 2021b); see Figure 4 for a map of the US highlighting expansion and non-expansion states.

The rates of uninsured have gone down for both expansion and non-expansion states, which can be in part attributed to the Affordable Care Act (ACA), as well as the lower unemployment rate, which is explained in more detail below (Antonisse, Garfield, Rudowitz, \& Guth, 2019; Shartzer, 2018; USC Institute for Families in Society, 2018). 
South Carolina child care providers' median annual salary of $\$ 19,480$ does not qualify for Medicaid in a non-expansion state (Health Reform: Beyond the Basics, 2019; Kaiser Family Foundation, 2019b, 2021b; U.S. Department of Health \& Human Services, 2019b). Family status of child care workers varies, but in SC, single child care workers without children (and also without special needs) are ineligible for Medicaid (Kaiser Family Foundation, 2021b; South Carolina Healthy Connections Medicaid, 2019). Raising eligibility for Medicaid for child care workers to $200 \%$ FPL $(\$ 25,760)$ would allow coverage of single, childless child care workers (U.S. Department of Health \& Human Services, 2021).

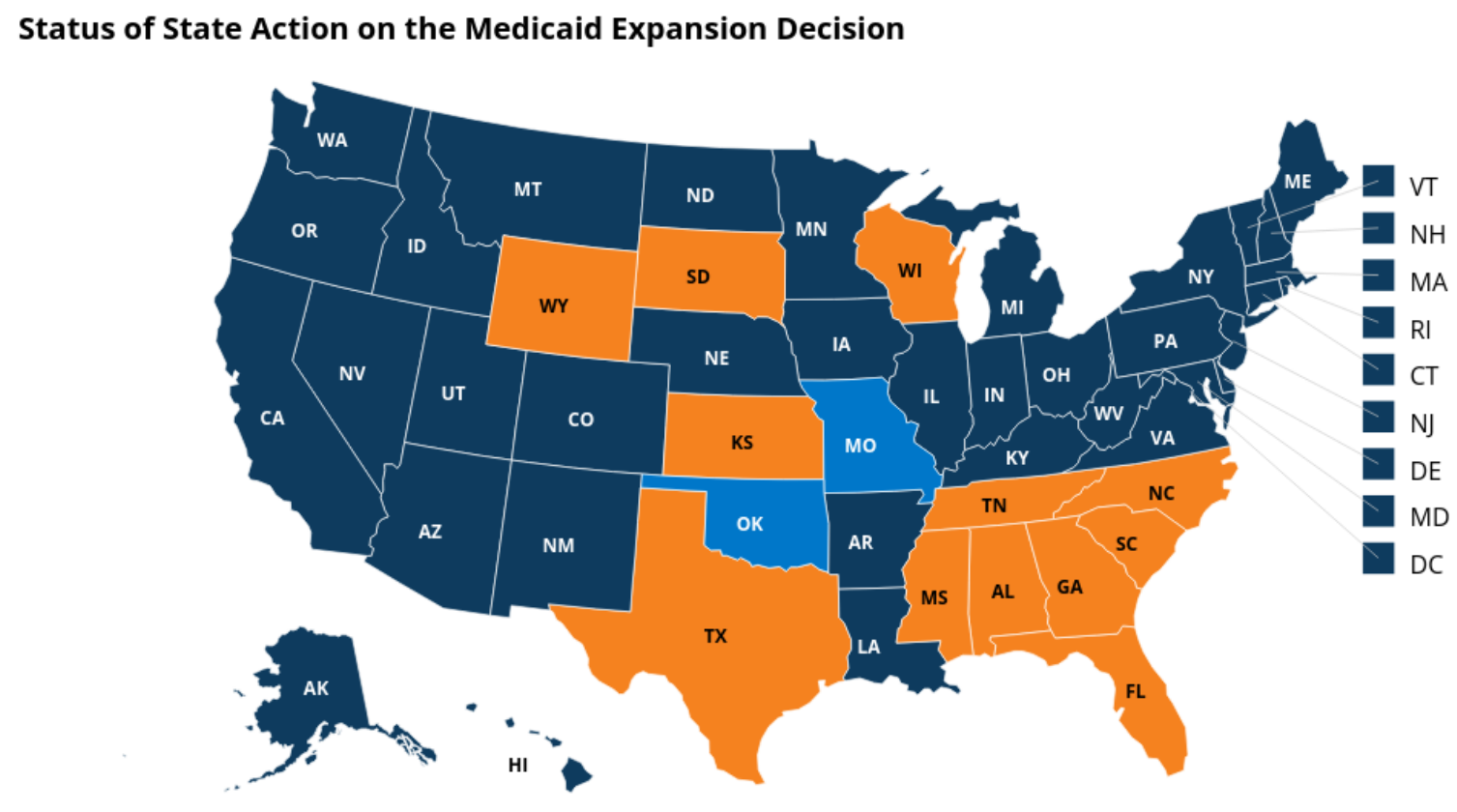

Adopted and Implemented $\quad$ Adopted but Not Implemented $\quad$ Not Adopted

SOURCE: Kaiser Family Foundation, kff.org

Figure 4. Map of US states that have expanded, adopted but not implemented, or not expanded Medicaid as of February 4, 2021. Data from Kaiser Family Foundation (2021b).

\section{Literature and Data Review}

\section{Method}

\section{Literature Search}

Relevant peer-reviewed, government documents, state and national data, and grey literature were reviewed and analyzed to: 1) review the current struggle that child care workers in the US (in general) and SC (in particular) experience compared with employees in other fields; 2) explore options that might improve pay or benefits; 3) review existing literature describing everyday life as a child care worker, particularly as it relates to the experience of living with low wages and a lack of employment benefits; 4) review existing literature describing how wages and benefits dictate job stability or switches between different 
child care facility types; and 5) look for evidence of what or whether child care workers have shared in testimonies about everyday life with policy makers. Search terms included (but were not limited to) 'child care teacher work life,' 'child care worker everyday life,' and 'child care worker stories.' Academic and non-academic databases used for the search were Nexis Uni, Google Scholar, Google (for gray literature), PubMed, PsycINFO, Academic Search Complete, and CINAHL Plus with Full Text. Included studies were English only, US-based, and did not include a date range.

Backward reference searching ${ }^{2}$ was also used to find additional literature not originally found within traditional literature search methods. Other methods of information gathering included Google alert subscriptions to 'early childhood' and 'child care,' as well as daily email updates from the Kaiser Family Foundation. The Center for the Study of Child Care Employment was also consulted for additional references.

\section{Data Sources}

Several publicly available sources for data on childcare workers, as well as literature about policies and the impact of low wage and lack of benefits were searched. Using data from the Bureau of Labor Statistics (Bureau of Labor Statistics, 2018a, 2018b, 2018c, 2019a, 2019b, 2019c, 2020a, 2020b), Centers for Medicare \& Medicaid Services (Centers for Medicare \& Medicaid Services, 2017, 2018, 2019a, 2019b, 2019c, 2019d, 2019e), Center for the Study of Child Care Employment (CSCCE) (Linnan et al., 2017; S. Thomason et al., 2018; Whitebook et al., 2018; Whitebook et al., 2014), Economic Policy Institute (2019), Institute for Child Success South Carolina Early Childcare Data Report (McDougald Scott et al., 2019), Kaiser Family Foundation (Hinton, Musumeci, Rudowitz, Antonisse, \& Hall, 2019; Kaiser Family Foundation, 2019a, 2019b, 2019c, 2019d, 2019e, 2021a, 2021b), National Survey of Early Care and Education (National Survey of Early Care and Education Project Team, 2020; National Survey of Early Care and Education Project Team (National Opinion Research Center), 2012), SC Department of Social Services Workforce Study (Rao \& Chen, 2018), U.S. Department of Health and Human Services (2019b, 2021), USC Institute for Families in Society (2018), and other publicly available data related to the compensation status of child care workers in SC and the US were analyzed.

\section{Results}

\section{Current Policies to Improve Access to Healthcare}

\section{The Affordable Care Act}

The Patient Protection and Affordable Care Act, otherwise known as the Affordable Care Act and the Health Care and Education Reconciliation Act of 2010, Affordable Care Act, ACA, or 'Obamacare,' was signed into law in 2010 by President Obama (U.S. Department of Health \& Human Services, 2019a). This analysis will refer to the Affordable Care Act as the ACA. The intent of the law was to increase access to coverage by expanding Medicaid, providing health insurance marketplaces (also known as exchanges), reduce the number of uninsured persons, and overall make health insurance more affordable and accessible for Americans (RAND Corporation, 2019a, 2019b; U.S. Department of Health \& Human Services, 2019a).

\footnotetext{
${ }^{2}$ The method of pulling relevant sources from article reference lists and database search suggestions (Florida Atlantic University Libraries, 2021).
} 
There are many controversial elements to the ACA, primarily due to political partisanship, but the data support that although flawed, the ACA has improved access to healthcare in the US (Antonisse et al., 2019; Manchikanti, Helm Ii, Benyamin, \& Hirsch, 2017; RAND Corporation, 2019b). Although the ACA has improved access to healthcare, many child care workers remain un- or underinsured, especially in non-expansion states (National Survey of Early Care and Education Project Team, 2020; Rao \& Chen, 2018; Whitebook et al., 2018). In the aforementioned 2018 SC Early Childhood Educator Workforce Study, only $30 \%$ of early childhood educators (ECEs) reported receiving insurance through their place of employment; furthermore, $8 \%$ of ECEs reported being covered by Medicaid, $14 \%$ were uninsured, and $28 \%$ of study participants did not answer the question about the type of health insurance they had (Rao \& Chen, 2018). Nationally, the numbers indicate an improvement in Medicaid enrollment for child care workers: pre-expansion (2009-2013) was 21\%, while post-expansion (2014-2016) was 30\% (Whitebook et al., 2018).

\section{Medicaid Expansion}

Medicaid expansion began for many states on January 1, 2014, although several states expanded before and have expanded since that date (Antonisse et al., 2019; Henry J. Kaiser Family Foundation, 2015; Kaiser Family Foundation, 2021b; McMorrow, Kenney, Long, \& Goin, 2016). Although SC has not expanded Medicaid, the state has benefitted from slight improvements in reducing the uninsured rate and increasing Medicaid enrollment. See Table 1 for a clear layout of the comparison between South Carolina's 2013 (which was before the ACA expansion in many states) and 2019 Health Insurance Coverage of adults living in poverty 19-64 under 100\% and 200\% FPL (Kaiser Family Foundation, 2021a).

Table 1.

South Carolina Medicaid Enrollment and Uninsured: 2013 vs. 2019

\begin{tabular}{llll}
$\begin{array}{l}\text { Adults living in } \\
\text { poverty ages 19-64 }\end{array}$ & Medicaid status & 2013 & 2019 \\
\multirow{2}{*}{$100 \%$ FPL } & enrolled & $31 \%$ & $36.2 \%$ \\
& uninsured & $43 \%$ & $31.6 \%$ \\
\hline \multirow{2}{*}{ 200\% FPL } & enrolled & $23 \%$ & $27 \%$ \\
& uninsured & $39 \%$ & $28.7 \%$ \\
\hline
\end{tabular}

Note. Data in this table are from the Kaiser Family Foundation (2021a).

The improvements in enrollment and uninsured shown in Table 1 (between 2013 and 2019) are likely due to several factors. First, the ACA required SC to increase its FPL levels for several groups who were already approved by the State, therefore expanding Medicaid access to some South Carolinians regardless of SC's decision not to expand (South Carolina Healthy Connections Medicaid, 2014). Second, in 2013, SC agreed to some of the recommended enrollment strategies from the Centers for Medicare \& Medicaid to increase open enrollment through the national health exchange, healthcare.gov (Centers for Medicare \& Medicaid Services, 2019b). In the US as a whole, expansion states have shown more progress than 
non-expansion states in reducing uninsured rates and increasing Medicaid enrollment (Antonisse et al., 2019; Shartzer, 2018).

\section{Medicaid Expansion Improves Health Outcomes.}

Several studies have indicated improved health outcomes among populations who live in Medicaid expansion versus non-expansion states (Antonisse et al., 2019; Lee, Shi, \& Liang, 2018; Robert Wood Johnson Foundation, 2019; Rudowitz, 2018; Sommers, Maylone, Blendon, Orav, \& Epstein, 2017), and one study found the same results from expansion state data before the ACA (McMorrow et al., 2016). Such improved outcomes were demonstrated from studies, analyses, and reports published by governments, policy organizations, and research institutions, utilizing various research methodologies ${ }^{3}$ (Antonisse et al., 2019; Lee et al., 2018; McMorrow et al., 2016; Pope, 2013; Pore, 2012; Robert Wood Johnson Foundation, 2019; Rudowitz, 2018; Sommers et al., 2017; Tipirneni et al., 2019). Health-related outcomes found to be positively affected in Medicaid-expansion states included:

- life expectancy in years

- decreases in uncompensated costs

- lower rates of hospital closures

- access to care

- primary care utilization

- quality of care

- utilization of services

- affordability of care

- patients seeking care earlier

- unemployment rate

- average number of persons participating in SNAP

- average number of monthly SNAP benefits per person

- emergency department visits

- expenses saved on exchange/insurance premiums

- increased access to behavioral health services and primary care appointments

- increased spending for opioid treatment

- larger decreases in one-year mortality from end-stage renal disease

- reduction in out-of-pocket spending

- financial security among the low-income population

- percentage of adults who reported not having a personal doctor

- percentage of adults who reported not seeing a doctor in the past 12 months because of cost.

\section{Medicaid Expansion and Work.}

Antonisse et al. (2019)'s extensive literature review on Medicaid expansion indicated that there is a growing body of literature reporting an improvement in employment and the labor market among states that expanded. These improvements were not due to work requirements; furthermore, most current

\footnotetext{
${ }^{3}$ Cross-sectional studies, literature reviews, difference in differences, and mixed methods were among the methodologies used.
} 
Medicaid recipients are already working (Antonisse et al., 2019; Garfield, Rudowitz, \& Orgera, 2019). An example of improvements in employment that may be attributed to expansion was found within studies of people with disabilities: in Medicaid expansion states, employment among the disabled population has increased compared to non-expansion states (Hall, Shartzer, Kurth, \& Thomas, 2018). This is particularly timely information due to the number of states actively trying to implement work and community engagement requirements for Medicaid enrollees (Hinton et al., 2019; Kaiser Family Foundation, 2019c). Further, Robert Wood Johnson Foundation (2019) reported that participants of Michigan and Ohio-based Medicaid coverage studies who had healthcare access through Medicaid expansion have found work to be easier. Closer examination of those studies found that Ohio participants also indicated that Medicaid expansion had made it easier to look for work (Kasich \& Sears, 2018), and the Michigan study participants reported that Medicaid expansion had helped them perform better at work, as well as get a better job (Tipirneni et al., 2019). ${ }^{4}$

One dissenting study was found regarding work and Medicaid expansion. A pre-ACA study (2000-2013) of expansion versus non-expansion states indicated that high school graduate women were seven percentage points less likely to be employed than similar women in states that had not expanded Medicaid (Bradley \& Sabik, 2018). These same results were not observed among men. Bradley and Sabik (2018) discuss several plausible reasons for the effects found in their study, which are all within the pre-ACA context: low-income women are less likely to be covered by employer-provided health insurance, more vulnerable to loss of insurance due to changes in marital status or family coverage, more likely to be uninsured - reported as $40 \%$ in 2013 for this population, higher premiums than men pre-ACA, and prevention from purchasing insurance due to pre-existing conditions (including pregnancy). It would be interesting to replicate this study's findings with 2014-2020 data, but the rest of the studies included in this analysis - including a robust literature review (Antonisse et al., 2019) — in addition to considering the context given for the Bradley and Sabik (2018) study findings, the author has confidence in the findings that employment is improved among low-income populations (including women) by expanding Medicaid access.

\section{Medicaid Expansion Improves Health Care Coverage for Low Wage Workers.}

Multiple states reported that expansion of Medicaid helps to cover low wage workers (including child care workers) who do not receive health insurance through their workplace-some even before expansion coverage began in many states on January 1, 2014 (Families USA \& States News Service, 2014a, 2014b, 2014c, 2014d, 2014e, 2015a, 2015b, 2015c, 2015d; Families USA \& Targeted News Service, 2014, 2015; Mahan, Families USA, \& States News Service, 2014; McMorrow et al., 2016; Michael in Norfolk, 2018; Pettus \& Associated Press State \& Local Wire, 2013; Pope, 2013; Pore, 2012; Potempa, 2002; Robertson, 2019; Senate Finance, March 15, 2001, Thursday; Stewart, 2014). States that have released such reports include:

- Alabama (Families USA \& States News Service, 2014a)

- Alaska (Potempa, 2002)

\footnotetext{
${ }^{4}$ It is important to note that Michigan and Ohio are both expansion states, and by contrast, the majority of Southern US states did not expand Medicaid. Data indicates that many Southerners who are enrolled in Medicaid are less likely to work than Medicaid enrollees in other regions of the US (Garfield et al., 2019); however, states who did not expand Medicaid have lower thresholds for eligibility, meaning that workers with low wages who qualify for Medicaid in expansion states may not qualify for Medicaid in non-expansion states.
} 
- Arkansas (Families USA \& States News Service, 2015a)

- Colorado (Pope, 2013)

- Kansas (Families USA \& States News Service, 2015b)

- Kentucky (Families USA \& Targeted News Service, 2015)

- Minnesota (Families USA \& States News Service, 2015c)

- Mississippi (Pettus \& Associated Press State \& Local Wire, 2013)

- Missouri (Families USA \& States News Service, 2014c)

- North Carolina (Robertson, 2019)

- Ohio (Families USA \& States News Service, 2015d)

- Pennsylvania (Families USA \& States News Service, 2014b)

- Utah (Stewart, 2014)

- Tennessee (Families USA \& States News Service, 2014d)

- Virginia (Families USA \& States News Service, 2014e; Michael in Norfolk, 2018)

- West Virginia (Pore, 2012)

- Wyoming (Families USA \& Targeted News Service, 2014).

Reporting improvement in coverage alone, data indicated an increase among low wage workers due to Medicaid expansion (Antonisse et al., 2019; Flint, 2014; Shartzer, 2018). In some cases, states who have implemented waivers, such as work requirements for receiving Medicaid, gains in coverage were compromised (Antonisse et al., 2019).

\section{Medicaid Waiver 1115}

\section{What is Medicaid Waiver 1115?}

Medicaid waiver 1115, the 'Research and Demonstration' waiver, allows for states to experiment with policies that may affect the low income population who is eligible for Medicaid (Centers for Medicare \& Medicaid Services, 2019a). Uses of this waiver have shifted based upon partisan priorities. For example, the waivers encouraged by some have targeted expanding or including access to Medicaid, while different leadership favored limiting access through such avenues as work and community engagement requirements (Hinton et al., 2019). Other current uses of the waiver include eligibility and enrollment restrictions; benefit restrictions, copays, healthy behaviors; behavioral health (most popular); delivery system reform; managed long-term services and supports; and 'other' targeted waivers (Kaiser Family Foundation, 2019c). With the new Biden administration, change is expected to be more inclusive for Medicaid access (Keith, 2021).

No states have specifically expanded for child care workers, but Oklahoma included nonprofit employees and other special populations in their 1115 waiver (Kaiser Family Foundation, 2019c; Oklahoma Health Care Authority, 2018a). Because many child care workers are employed by non-profit centers, the expansion to non-profit individuals who are not covered by employee-provided insurance could benefit from this type of expansion.

\section{Why did Oklahoma use the waiver for special populations?}

In 1995, the Oklahoma Health Care Authority began administrating Oklahoma's Medicaid program, and submitted its 'SoonerCare' 1115 waiver, which was approved to begin January 1, 1996 (Oklahoma Health 
Care Authority, 2005, 2013). The initial 1115 waiver was designed to develop and implement managed care delivery systems, as a response to state-supported research into what should and could be done to alleviate rising Medicaid enrollment and costs (Oklahoma Health Care Authority, 2005). Over time, Oklahoma has expanded access to several groups who were not in the initial waiver (Oklahoma Health Care Authority, 2005), and among the included groups were non-profit employees (Oklahoma Health Care Authority, 2013). ${ }^{5}$

Although non-profit employees are entitled to this insurance plan, there seem to have been no attempts, and there are no planned efforts to enroll non-profit employees (Oklahoma Health Care Authority, 2018b; M. Thomason, 2019). ${ }^{6}$ Thus, there are also no data to indicate the impact of waiver inclusion for nonprofit employees (Oklahoma Health Care Authority, 2018b).

\section{Medicaid Expansion would Benefit South Carolina Child Care Providers.}

South Carolina child care providers' median annual salary of $\$ 19,480$ does not qualify for Medicaid in a non-expansion state, but would qualify for Medicaid in an expansion state if the child care worker has a two-or-more-person household (Bureau of Labor Statistics, 2020b; Economic Policy Institute, 2019; Health Reform: Beyond the Basics, 2019; U.S. Department of Health \& Human Services, 2019b). The maximum annual income for SC Medicaid eligibility is $\$ 11,671$ (67\% FPL) for single parents of one child (Kaiser Family Foundation, 2021b; U.S. Department of Health \& Human Services, 2021), and standard Medicaid expansion would raise that eligibility to $138 \%$ FPL, which would be $\$ 24,040$ for a single mother with one child (Kaiser Family Foundation, 2021b; U.S. Department of Health \& Human Services, 2021). This means that $\$ 190$ a year ( $\$ 16$ a month) keeps them from getting assistance on their access to healthcare. Both single parents with one child and single child care workers with no children would need Medicaid expansion to be at $200 \%$ FPL to qualify, which is $\$ 25,760$ (U.S. Department of Health \& Human Services, 2021).

Family status of child care workers varies, but for the child care worker who is unmarried and has no children, it is worth noting that single persons (without special needs) without children in SC are ineligible for Medicaid (Centers for Medicare \& Medicaid Services, 2019b; Kaiser Family Foundation, 2021 b). Therefore, some child care workers with children may already be eligible for Medicaid, due to the size of their household and income, but expansion of Medicaid would cover the low-income workers who cannot be covered under the current SC policy.

\section{Current Policies Designed to Improve Child Care Wages}

Improving child care wages requires a complex mix of efforts, due to the nature of how child care is funded (Gould et al., 2017; S. Thomason et al., 2018; Whitebook et al., 2018). Since child care is not funded directly through federal or state funds, the cost of child care is already high, and wages already make up a considerable portion of child care expenditures, it is difficult for centers to raise prices to cover

\footnotetext{
${ }^{5}$ Although non-profit workers were always non-explicitly covered under SoonerCare, the expansion to non-profit employees within organizations staffed by 500 or fewer employees, and up to and including 100\% FPL occurred through an amendment effective January 1, 2010 (Centers for Medicare \& Medicaid Services, 2019c; Leavitt Partners, 2013; Oklahoma Health Care Authority, 2013, 2018a, 2018b, 2019; M. Thomason, 2019).

${ }^{6}$ In conversation with Melinda Thomason, the Senior Director for Stakeholder Engagement at the Oklahoma Health Care Authority, it was revealed that there had been an emphasis on enrolling traditional Chamber of Commerce businesses and their employees into Insure Oklahoma, rather than non-profit organizations (M. Thomason, 2019).
} 
wage increases as may be typical in other industries (Gould et al., 2017; S. Thomason et al., 2018; Whitebook et al., 2018). Furthermore, as previously stated, an increase in wages or benefits with the child care system as it currently is would incur greater cost to parents, many of whom cannot afford this increase (Malik, 2019). Public funding increases and child care systems improvements are necessary to improve the pay for child care workers (Gould et al., 2017; S. Thomason et al., 2018; Whitebook et al., 2018). Efforts to expand pay include local and federal advocacy; research (and publications); and programs such as Child Care and Development Block Grants (CCDBG), T.E.A.C.H., and WAGE\$. Renewed federal efforts to improve child care systems, including pay, quality, affordability, and more, have been introduced in Congress via the Child Care for Working Families Act of 2019 (Child Care for Working Families Act of 2019, 2019).

Local and federal advocacy and research efforts come from many organizations such as the Center for American Progress (2017), Child Care Aware (2019), the National Association for the Education of Young Children (NAEYC) (2019) and its state chapters (SCAEYC in South Carolina), the Institute for Child Success (ICS) (2019), the CSCCE (2019), New America (2019), the First Five Years Fund (2019), and more ${ }^{7}$. Although there are many interested parties who have been working on increasing pay for child care workers, success has been limited and not as effective as would be desired. Currently, there are efforts underway to increase the federal minimum wage to $\$ 15$ (Keith, 2021; The White House, 2021), which could cause additional problems for the child care industry due to the cost of running child care centers (National Center on Early Childhood Quality Assurance, 2015). True societal and systems change is needed to make progress in raising pay for child care workers - and a broader understanding of what child care workers do each day is needed to bolster the societal will to back up the increased investment in child care wages and benefits (McDougald Scott, 2021a). ${ }^{8}$

\section{Child Care and Development Block Grants}

Child Care and Development Block Grants (CCDBG grants), first enacted in 1990, provide federal money to states to fund child care vouchers for low-income families and improvements to quality and overall child care systems (First Five Years Fund, 2021; Office of Child Care, 2019). Guidelines accompanying the CCDBGs indicate that funds should be used to help with teacher compensation, but are not required to be used in that way. The money set aside for compensation improvement is limited due to the local market rates and costs of centers who receive these grants - which are by statute centers who serve low-income parents (Office of Child Care, 2019; Whitebook et al., 2014).

\section{Teacher Education and Compensation Helps}

Teacher Education and Compensation Helps, best known as T.E.A.C.H., is a national model, overseen in South Carolina by the Center for Child Care Career Development (CCCCD) (South Carolina Center for Child Care Career Development, 2019a). Nationally, 23 states are using the T.E.A.C.H. model (T.E.A.C.H. Early Childhood National Center, 2019b). T.E.A.C.H. Early Childhood ${ }^{\circledR}$ South Carolina provides financial support for members of the early childhood workforce completing higher degrees. Support is available for teachers, directors, center owners, and family/group individuals working in

\footnotetext{
${ }^{7}$ The author appreciates everyone's research and advocacy efforts on this front, but an exhaustive list is out of scope for this paper.

${ }^{8}$ See McDougald Scott (2021a, 2021b) for more on this.
} 
child care to complete coursework in early childhood education (South Carolina Center for Child Care Career Development, 2019b).

This program covers between 60 and $85 \%$ of tuition costs, and participating centers are required to pay at least $10 \%$ of the credential scholarship (potentially up to $25 \%$ for associate and bachelor's level teachers), with individuals covering the final 10-20\%. Teachers utilizing scholarships are required to maintain their employment at the center while working on their degree, and associate and bachelor's candidates are required to maintain employment at their sponsoring center for at least one year past their contract date (South Carolina Center for Child Care Career Development, 2019b).

Although T.E.A.C.H. is a program that provides support for continuing education among those states that use it, this should not be seen as an increase in pay. The time out of the classroom and additional money coming out of teachers' take-home pay could be seen as a short-term sacrifice for a long-term gain if pay scales are set up such that the child care provider (the teacher in this situation) will receive a pay increase when the coursework is completed. Even the long-term gain in wages for child care workers may not be a living wage.

\section{WAGE\$}

WAGE $\$$ is a program designed to provide salary supplements to early child care educators (Child Care Services Association, 2021). The money usually takes the form of stipends for furthering early childhood education or supplements for teachers who have attained educational or longevity benchmarks (T.E.A.C.H. Early Childhood National Center, 2019a; Whitebook et al., 2014). WAGE\$ reports a $11 \%$ average turnover rate (compared to the $13 \%$ national average), $\$ 861$ average six-month supplement, and 7,374 supplement recipients in 2018-2019 (T.E.A.C.H. Early Childhood National Center, 2019a). These stipends and supplements are welcome, but limited and susceptible to changing political desires (Whitebook et al., 2014).

\section{The American Rescue Plan Act of 2021}

The American Rescue Plan Act of 2021 (2021) was signed into law on March 11, 2021. This bill provides critical support for child care (and others) due to the devastation COVID-19 has caused for the child care workforce. It provides funds for: (a) new child care providers to open; (b) centers that closed due to COVID; (c) personnel, benefits, and insurance premium pay; (d) costs for employee recruitment and retention; (e) rent and insurance related to rent or mortgage; (f) personal protective equipment and all supplies related to cleaning; $(\mathrm{g})$ training and personal development for employees related to health, and safety; (h) purchases or updates of COVID-related equipment; (i) goods and services to maintain or resume child care services; (j) mental health supports for children and employees; and (k) additional Head Start funding for the above expenses. It also provides child tax credits, that will help families with costs associated with caring for children. This American Rescue Plan Act may help to persuade legislators of the importance of child care to our economy and lead them to make more permanent provisions for bolstering the child care field.

However, the provisions in the American Rescue Plan Act of 2021 (2021) are not permanent, as many of them are set to expire on September 30, 2021. Therefore, advocacy efforts to make relevant improvements from the American Rescue Plan Act of 2021 (2021) permanent, as well as for provisions of the American 
Families Act, American Families Plan, and Senator Murray's Child Care for Working Families Act (detailed below) should continue.

The Biden Administration is also currently working to develop proposals to expand enrollment and eligibility through the federal exchange on HealthCare.gov (Keith, 2021), and strides towards this were made in the American Rescue Plan Act of 2021 (2021). In the American Rescue Plan Act of 2021 (2021), relief from high premiums and expanded access to enrollment in health exchanges were added, so that no one who purchases insurance on the health exchange will pay more than $8.5 \%$ of their income ( $\$ 138$ per month for SC child care median income). However, as noted previously, these adjustments are temporary (Huetteman, 2021). These actions will improve the low wages and access to health care for child care workers, however payment of $\$ 138$ per month is still a lot of money out-of-pocket of someone who makes $\$ 19,480$ a year (or $\$ 1,623$ per month). Access to Medicaid would be a better solution, which would make it possible for child care workers to earn the median wage if the limit were raised to 200\% FPL (\$25,760 for a single person (U.S. Department of Health \& Human Services, 2021)).

\section{American Families Act of 2021 and American Families Plan}

The American Families Act of 2021 (2021), introduced on February 8, 2021, would make the fullyrefundable tax credits from the American Rescue Plan Act permanent, and also establishes monthly payments of these tax credits, supporting families throughout the year. This Act upholds a central piece of the Biden Administration's American Families Plan (and American Jobs Plan), which is designed to expand upon and make more permanent the work of the American Rescue Plan Act (The White House, 2021).

One of the provisions of the American Families Plan is to provide high-quality, universal three- and fouryear old preschool. Within the plan to expand preschool, teachers will be compensated at a minimum of $\$ 15$, with pay scales and benefits comparable to Kindergarten teachers. The minimum wage increase raises point of concern as to whether the child care industry will be able to afford this additional expense. A reduction in turnover may help defray some of these costs of an increase, but it would take some time for child care centers to realize this savings. Passing the cost on to the parents will likely be the solution if this is the requirement, and that would make child care even more of a cost burden for families.

The American Families Plan also provides support for teachers who are pursuing their relevant degrees and credentials - and expanding the existing scholarships and supports for teachers to early childhood educators. These promising plans are currently being negotiated between the White House and Congress (Kim, DeBonsis, \& Stein, 2021). The success of these proposals' passage into law is to be determined, and special attention will be paid to see what remains in them and how they are implemented.

\section{Child Care for Working Families Act}

The Child Care for Working Families Act was (re-)introduced both in the U.S. House of Representatives and the U.S. Senate on April 22, 2021 and referred to the House Committee on Education and Labor and Senate Committee on Health, Education, Labor, and Pensions, respectively (Child Care for Working Families Act H.R. 2817, 2021; Child Care for Working Families Act S. 1360, 2021). If enacted, strides would be made towards improving the state of child care and early childhood in the US . Relevant to this analysis, it would improve child care workforce compensation and training by requiring at least a living 
wage, as well as comparable pay with elementary school teachers of similar training and credentials (Child Care for Working Families Act H.R. 2817, 2021; Child Care for Working Families Act S. 1360, 2021). How this Act could help implement the measures of the American Families Plan is yet to be determined at the time of this article's publication.

\section{Discussion and Recommendations}

The systems that surround child care are complex, which is often the reason cited for low pay for child care workers. However, the pay and lack of benefits provided for many child care workers in SC, as well as nationally, is deeply problematic. Child care workers make less money than their similarly-qualified peers working in early childhood education, as well as less than the workforce as a whole, and are afforded fewer benefits. Raising pay is a complex solution requiring an overhaul of the early childhood education system, which will take a larger-scale plan of action and public support to implement (see McDougald Scott (2021a) or McDougald Scott (2021b) for more details). The current political climate (2021) includes a new Presidential Administration interested in improving access to child care, increasing the minimum wage to $\$ 15$ an hour, and other benefits such as paid leave that would improve the working environment for child care professionals. However, the proposals set forth in the American Families Act are currently being contested in an extremely partisan environment, and it remains to be seen which parts - if anywill be passed (Kim et al., 2021). In the shorter-term, perhaps emphasis could be placed on improving benefits and workforce environments.

Healthcare for child care workers is a necessity, and current healthcare policy does not adequately cover workers who earn low wages, particularly in US states that did not expand Medicaid. While many people who are enrolled in Medicaid currently work, additional requirements and barriers to access to Medicaid only creates further burden on low wage earners who are trying to get by each day (Garfield et al., 2019). In fact, the child care crisis is keeping women out of the workforce, causing them to cut back on hours worked, or leave the workforce - a situation that has been exacerbated by COVID-19 (Dockterman, 2021; Kashen, Glynn, \& Novello, 2020; Schochet, 2019).

Child care and healthcare are in conflict due to the fact that child care workers earn low wages, but do not qualify for stringent Medicaid requirements-especially in non-expansion states. As this review has demonstrated, healthcare is a requirement for child care workers to provide quality child care, and the current conditions do not provide for quality outcomes. Child care professionals who lack access to healthcare risk their own health, which also affects the health of those around them, an issue that was elevated as a concern during COVID-19. During COVID-19, child care workers reported feeling that their health was overlooked by society as their own health was reliant upon the children and families in their care following public health and safety guidelines (McDougald Scott, 2021a). Lack of attention to health on the part of children and families in their care risks the health (and potentially lives) of the child care workers, and furthermore could lead to further transmission of COVID-19. Lack of access to healthcare endangers the health of both child care professionals and society.

Child care workers are in poor health in comparison to other professionals of similar socioeconomic standing and women who do not work (Linnan et al., 2017; Otten et al., 2019; Whitaker et al., 2013). Because child care workers are not afforded benefits, which is in direct conflict with taking care of their overall wellbeing as they care for our children, high turnover rates and increased cost for healthcare due 
to the lack of preventive care are persistent outcomes for this population. Providing access to Medicaid one temporary fix to supplement child care income, but federal support for child care is the ultimate solution.

\section{Discussion of Proposed Solutions}

\section{Medicaid Expansion for All}

Although Medicaid expansion for all may be the best solution to benefit all workers in SC and other nonexpansion states, it is not currently a politically viable option. However, putting Medicaid expansion on the ballot as a referendum in SC might succeed. Recently, a Winthrop poll indicated that $73 \%$ of South Carolinians would be supportive of expanding Medicaid (Bohatch, 2020). The difficulty is that the majority of the General Assembly, as well as the SC governor, continue to oppose Medicaid expansion, and they collectively may continue to block legislative efforts to put it on the ballot (Bohatch, 2020). As recently as 2018, Medicaid expansion was included as a platform issue in the SC governor's race, but was flatly rejected by voters as evidenced by re-election of the Republican incumbent who supported the previous popular governor who had vowed to never expand Medicaid in SC (ABC News Radio, 2013; Floyd, 2019; Sausser, 2017). However, it might be possible for South Carolina citizens to call for Medicaid expansion to be on the ballot (National Conference of State Legislatures, 2012). Further research and work are needed for citizens to put Medicaid Expansion on the ballot in SC. Other Southern and conservative-leaning states, including Florida, Mississippi, and South Dakota, have active campaigns to include Medicaid expansion on their voter ballots (Brown, 2021). These campaigns are following the example of other states (Maine, Idaho, Nebraska, Utah, Oklahoma, and Missouri) that placed Medicaid expansion on the ballot, resulting in Medicaid expansion for those states (Brown, 2021; Jaspen, 2019).

There is no current productive push for Medicaid expansion to be on the ballot in SC. For states like SC, the most effective and expedient option would be to submit an application for a Medicaid waiver 1115 to expand coverage to provide health insurance via Medicaid for child care workers.

\section{Expand Medicaid for Child Care Workers}

This policy analysis has demonstrated that Medicaid expansion for child care workers should improve their health outcomes, make it easier for them to perform their jobs, and allow them to keep approximately $\$ 1,092^{9}$ that they may have otherwise spent on health care each year. Medicaid expansion ultimately benefits not only the workers, but also children and families, as well as ultimately all taxpaying citizens and members of society living within the state.

Currently, the South Carolina Department of Social Services (DSS), which licenses child care facilities estimates that there are 23,696 child care providers in South Carolina (SC) (Leach, 2021). This number translates to $.01 \%$ of the 2,107,760 people in the SC workforce (Bureau of Labor Statistics, 2020a), and expanding Medicaid would greatly benefit them. Useful data points about the overall situation for child care workers in SC and the US are provided in Table 2. The estimated number of child care workers provides a scope for how many workers are affected by the issue of low wages and scant benefit

\footnotetext{
${ }^{9}$ This number is based on the calculation provided in Table 2 for annual health care costs $(\$ 985)$, plus an annual cost estimate provided on healthcare.gov for a single woman, age 36, with no dependents $(\$ 1,199)$, averaged.
} 
availability. The average income, poverty level to receive Medicaid, and current cost of Marketplace insurance for child care workers is included in Table 2 to demonstrate the impact of such a cost on this population. Additionally, the number of uninsured child care workers is included; this helps highlight the overall utility of Table 1: covering child care workers under a Medicaid waiver which would be impactful to the lives of child care workers and should not create a large burden for the state of South Carolina.

\section{Table 2: Child Care Worker Indicators at a Glance: South Carolina and the United States}

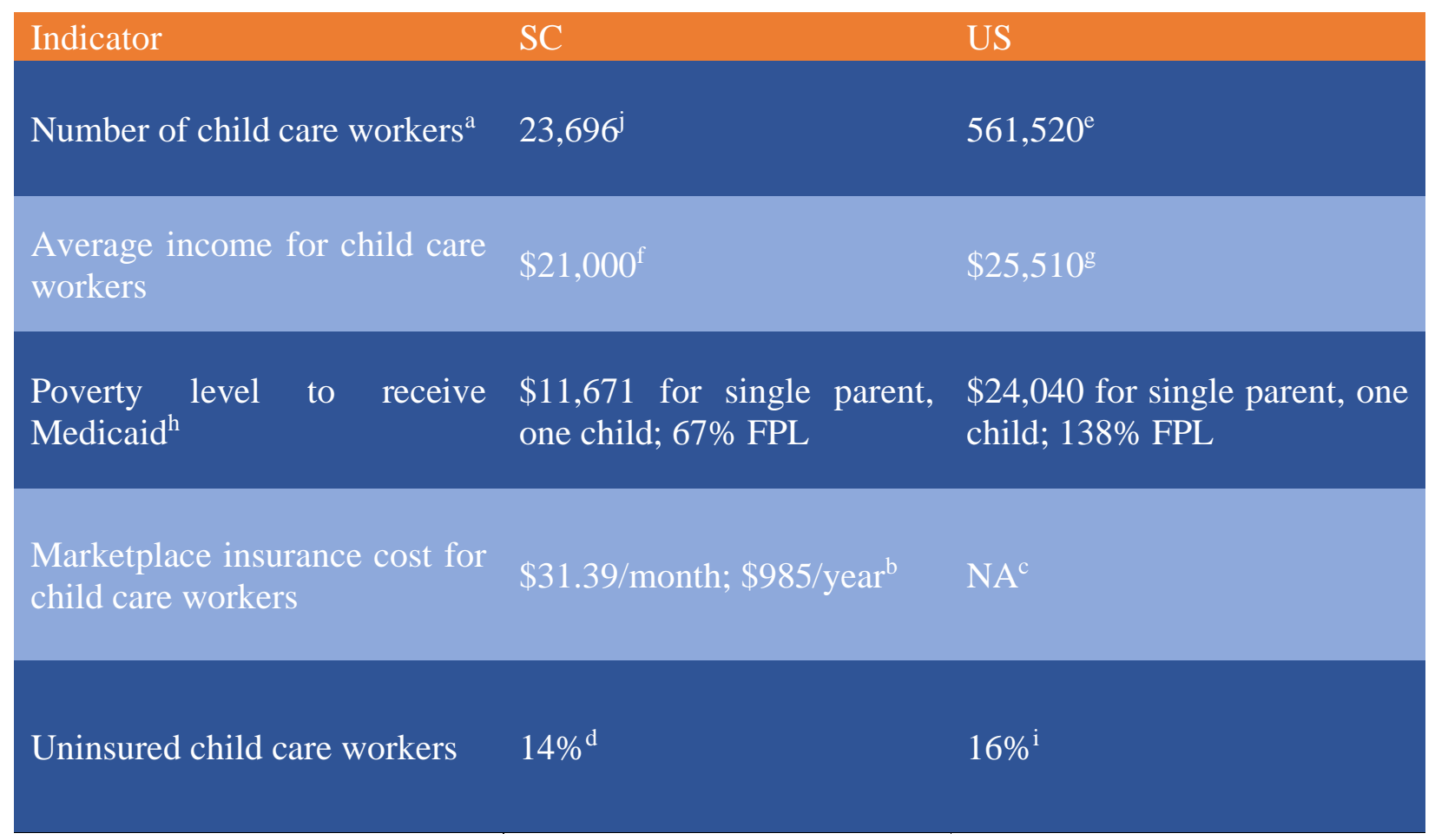

Note. FPL $=$ Federal Poverty Limit according to U.S. Department of Health \& Human Services (2021).

${ }^{a}$ Total includes the following occupations as defined by the U.S. Bureau of Labor Statistics Occupational Employment Statistics (OES): 'child care workers,' 'preschool teachers, excluding special education,' 'preschool teachers, special education,' 'education administrators: preschool/child care center programs.' These data do not include the self-employed, although home-based child care assistants, who are employees, are likely included in the 'child care worker' category. Due to the limited data available across states in the OES, state-based surveys or registries may provide more comprehensive estimates of the Early Childhood Education workforce.

${ }^{\mathrm{b}}$ These numbers are based on https://www.healthcare.gov/see-plans/\#/plan/results: 1 parent, 13 -year-old, \$19,570 annual income (based on 2019 data when this calculation from healthcare.gov could be obtained), $\$ 482$ subsidy for a BlueCross BlueShield of South Carolina BlueEssentials Silver 14 plan.

${ }^{\mathrm{c}}$ This value for the US as a whole is not applicable (NA). Each state has its own limits and allowances, and the amount also varies by state expansion status.

${ }^{\mathrm{d}}$ Percentage based on percentage of sample that was uninsured from Rao and Chen (2018).

${ }^{\mathrm{e}}$ Data from Bureau of Labor Statistics (2020a).

${ }^{\mathrm{f}}$ Data from Bureau of Labor Statistics (2020b).

${ }^{\mathrm{g}}$ Data from Bureau of Labor Statistics (2020a).

${ }^{\text {h }} 138 \%$ FPL is the Medicaid expansion level. Data from Kaiser Family Foundation (2021b); U.S. Department of Health \& Human Services (2021).

${ }^{\mathrm{i}}$ Data from National Survey of Early Care and Education Project Team (2020).

${ }^{\mathrm{j}}$ Data from SC Department of Social Services Director Michael Leach (2021). 


\section{Recommendation: Use Medicaid Waiver 1115 to Expand Healthcare Benefits to Child Care Workers}

Since it is unlikely that Medicaid will be put on the ballot in South Carolina in the near future, a more immediate solution would be to apply for Medicaid Waiver 1115 to include a special population: child care workers. Such a waiver could provide health care access to child care workers who do not currently have it, as well as to those who are currently enrolled in the exchange or are paying high premiums outof-pocket. Oklahoma originally used Medicaid waiver 1115 to expand access to health insurance for special populations before making their decision to expand Medicaid. The fact that Oklahoma was approved to use the 1115 waiver for special populations indicates that this is a possibility that could be applied in SC.

Oklahoma also originally stipulated eligibility for Medicaid coverage in their individual plan would be $250 \%$ FPL, then lowered it to $200 \%$ FPL before being required by the ACA to lower it to $100 \%$--which would not have happened if Oklahoma had originally expanded Medicaid (Centers for Medicare \& Medicaid Services, 2019c; Oklahoma Health Care Authority, 2019; M. Thomason, 2019). Therefore, there is also precedent for fellow non-expansion states using the 1115 waiver for coverage of special populations at $200 \%$, which is the minimum needed to cover low-wage child care workers regardless of household size. Single, childless child care workers making up to $\$ 31,225$ would be covered if FPL is set at $250 \%$ FPL under this waiver (U.S. Department of Health \& Human Services, 2019b).

Medicaid expansion for child care workers would likely improve their health outcomes, make it easier for them to perform their jobs, and allow them to keep approximately $\$ 1,092^{10}$ that they may have otherwise spent on health care each year. Medicaid expansion ultimately benefits not only the workers, but also children and families, as well as ultimately all taxpaying citizens and members of society living within the state.

\section{Other Groups that may be Included in Medicaid Waiver 1115.}

If expanding Medicaid can provide healthcare benefits for child care workers, that coverage population also be extrapolated to other important service providers who do not typically receive (at least adequate) health care benefits or make a minimum wage. Such helping professions may include home health workers, non-profit employees, or other domestic workers (such as nannies or house cleaners) (The Hatcher Group, 2019). Actual wages for domestic workers may often go un-reported, and non-profit wages vary widely by state and sector, but recent labor statistics indicate that the US annual median wage for home health aides and personal care aides is \$26,440 (Bureau of Labor Statistics, 2020a). States may look into specifying that those in helping professions who make low wages and do not have access to healthcare benefits may be eligible for Medicaid. These are the employees who support the economy and families by doing the work in homes, and with loved ones that allows others to go to work outside of their homes each day.

\footnotetext{
${ }^{10}$ This number is based on the calculation provided in Table 2 for annual health care costs (\$985), plus an annual cost estimate provided on healthcare.gov for a single woman, age 36, with no dependents $(\$ 1,199)$, averaged.
} 


\section{Future Research}

Future research could expand upon several areas. First, if Medicaid waiver 1115 for child care workers and other helping professionals is submitted, it could evaluate the health outcomes provided in this analysis, workforce environment impact, and impact on turnover rates for child care workers. Second, the potential cost-savings that may be realized due to expansion to child care providers and other low-wage workers in the helping professions should be examined. Some cost-savings may be realized through preventive care or reduced emergency department visits, as well as other improved health outcomes previously cited on pages 19-20. The saved money previously used for medical-related expenses may then be re-allocated for other programs, services, or expenses to make life for South Carolinians better. Third, benefits may include a better-prepared workforce - present and future, which would be fascinating to examine.

\section{Improvement of Work Environments}

Concrete efforts can also be taken to improve the work environments for child care workers through policy and advocacy efforts, such as: (a) identifying a sustainable source of public funding to improve wages; (b) creating a wage scale; (c) providing paid time off, planning time, predictable work schedules, adequate staffing, and a substitute pool; (d) creating guidelines for educational standards in staffing that are compliant with best practices; and (e) providing an accountability framework to make sure these items occur (Howes, Whitebook, \& Phillips, 1992; Schlieber, Whitebook, Austin, \& Hankey, 2019; Whitebook et al., 2018; Whitebook et al., 2014; Whitebook \& Sakai, 2003).

\section{Conclusion}

There have been ongoing efforts for decades to improve the pay for child care workers — with mixed results. Progress for earning a living wage will require a systems overhaul for early education, but child care providers cannot wait for workforce environmental improvements. Action must be taken now to augment the shortage of healthcare access for child care providers. In SC, Medicaid helps some child care workers receive access to health care, but expansion through Medicaid waiver 1115 would include many more child care workers who do not currently have access. Additionally, including other workers in the helping professions would afford some of our most valuable workers - the ones who allow us to live, work, and play more easily — the health care benefits they deserve.

Ultimately, in order to provide child care for all who need it, the US needs to consider early childhood education as a fundamental and necessary resource for all families. Like public education, child care must be considered a right for all children in the US, and supported as such. Ensuring living wages and access to health for those who provide child care is an essential component of providing quality early childhood care. We must invest in our present and future population now.

\section{Author Bio}

Amanda McDougald Scott, PhD received her doctorate from Clemson University in the Institute on Neighborhood and Family Life, Master of Science from Augusta State University in Applied Experimental Psychology, and Bachelor of Arts from the University of South Carolina in Experimental 
Psychology. She is a researcher, advocate, mother of a preschooler, and former candidate for County Council. Dr. McDougald Scott's background in academia; starting non-profits; community engagement; volunteering; and passion for working towards big goals using strategic, actionable steps has led her to advocate for solutions that will make life more equitable for all.

Dr. McDougald Scott has an array of both interests and areas of training, and her understanding of systems - that all areas of policy must work well with together to create a more meaningful whole - allows her flexibility in her approach to different topic areas. She also has much experience with building diverse and inclusive coalitions to work towards common goals. For the past seven years, Dr. McDougald Scott has been a community and policy researcher, which fuels her advocacy for early childhood with a special focus on child care. Kindergarten readiness is workforce readiness for children, families, and employers.

\section{Bibliography}

ABC News Radio (Producer). (2013, October 25, 2019). Gov. Nikki Haley vows no Medicaid expansion in South Carolina. http://abcnewsradioonline.com/health-news/gov-nikki-haley-vows-nomedicaid-expansion-in-south-carolina.html

American Family Act of 2021, H. R., 117th Congress. (2021). https://www.congress.gov/bill/117th-congress/housebill/928/text?q=\%7B\%22search\%22\%3A\%5B\%22HR+1\%22\%5D\%7D\&r=24\&s=1

American Rescue Plan Act of 2021, H. R., 117th Congress. (2021). https://www.congress.gov/bill/117th-congress/housebill/1319/text?q=\%7B\%22search\%22\%3A\%5B\%22COVID\%22\%5D\%7D\&r=1\&s=2\#tocH4276CEB3498041C19E048AF75169A4B1

Antonisse, L., Garfield, R., Rudowitz, R., \& Guth, M. (2019). The effects of Medicaid expansion under the ACA: Updated findings from a literature review. : http://files.kff.org/attachment/Issue-BriefThe-Effects-of-Medicaid-Expansion-Under-the-ACA-Updated-Findings-from-a-LiteratureReview

Bohatch, E. (2020, December 18, 2020). Should SC expand Medicaid? Some lawmakers want voters to weigh in. The State. https://www.thestate.com/news/politics-government/article247924335.html

Bradley, C. J., \& Sabik, L. M. (2018). Medicaid expansions and labor supply among low-income childless adults: evidence from 2000 to 2013. International Journal Of Health Economics And Management. doi:10.1007/s10754-018-9248-x

Brown, C. (2021). Medicaid expansion ballot measures brewing in three more states. https://news.bloomberglaw.com/health-law-and-business/medicaid-expansion-ballot-measuresbrewing-in-three-more-states

Bureau of Labor Statistics, U.S. Department of Labor. (2018a). Household data annual averages, median weekly earnings of full-time wage and salary workers by selected characteristics. https://www.bls.gov/cps/cpsaat37.pdf

Bureau of Labor Statistics, U.S. Department of Labor. (2018b). Occupational employment statistics, occupational employment and wages, May 2018.

https://www.bls.gov/oes/current/oes392021.htm\#st

Bureau of Labor Statistics, U.S. Department of Labor. (2018c). Occupational employment statistics, occupational employment and wages, May 2018, 39-9011 childcare workers. https://www.bls.gov/oes/current/oes399011.htm 
Bureau of Labor Statistics, U.S. Department of Labor. (2019a). Current employment statistics - CES (National). https://www.bls.gov/opub/ee/2019/ces/summarytable_201909.htm

Bureau of Labor Statistics, U.S. Department of Labor. (2019b). Occupational employment and wages, May 2018, 21-1099 community and social service specialists, all other. https://www.bls.gov/oes/current/oes211099.htm

Bureau of Labor Statistics, U.S. Department of Labor. (2019c). Occupational employment statistics, OES data. https://www.bls.gov/oes/tables.htm

Bureau of Labor Statistics, U.S. Department of Labor. (2020a). May 2019 national occupational employment and wage estimates United States. https://www.bls.gov/oes/current/oes_nat.htm.

Bureau of Labor Statistics, U.S. Department of Labor. (2020b). May 2019 state occupational employment and wage estimates South Carolina. https://www.bls.gov/oes/current/oes_sc.htm\#39-0000.

Bureau of Labor Statistics, U.S. Department of Labor. (2020c). Occupational employment statistics, occupational employment and wages, May 2019, 39-9011 childcare workers. https://www.bls.gov/oes/current/oes399011.htm.

Center for American Progress. (2017). Helping state and local officials advocate for child care. https://www.americanprogress.org/issues/early-childhood/news/2017/04/06/430185/helpingstate-local-officials-advocate-child-care/

Center for the Study of Child Care Employment. (2019). About us. https://cscce.berkeley.edu

Centers for Medicare \& Medicaid Services. (2017). Annual Reporting Data File: FY 2017 Data. https://www.medicaid.gov/medicaid/benefits/epsdt/index.html

Centers for Medicare \& Medicaid Services. (2018). October 2018 Medicaid \& CHIP Enrollment Data Highlights. https://www.medicaid.gov/medicaid/programinformation/medicaid-and-chip-enrollment-data/report-highlights/index.html

Centers for Medicare \& Medicaid Services. (2019a). About Section 1115 demonstrations. https://www.medicaid.gov/medicaid/section-1115-demo/about-1115/index.html

Centers for Medicare \& Medicaid Services. (2019b, July 2019). Medicaid \& CHIP in South Carolina. https://www.medicaid.gov/state-overviews/stateprofile.html?state=South-Carolina

Centers for Medicare \& Medicaid Services. (2019c). Oklahoma 1115 SoonerCare approval letter, Project Number: 11-W-00048/6. https://www.medicaid.gov/Medicaid-CHIP-Program-Information/ByTopics/Waivers/1115/downloads/ok/ok-soonercare-ca.pdf

Centers for Medicare \& Medicaid Services. (2019d). Oklahoma SoonerCare fact sheet. https://www.medicaid.gov/Medicaid-CHIP-Program-Information/By-

Topics/Waivers/1115/downloads/ok/ok-soonercare-fs.pdf

Centers for Medicare \& Medicaid Services. (2019e). See plans \& prices. https://www.healthcare.gov/see-plans/\#/

Child Care Aware of America. (2019). Advocacy \& public policy. https://usa.childcareaware.org/advocacy-public-policy/

Child Care for Working Families Act H.R. 2817, t. C. (2021). https://www.congress.gov/bill/117th-congress/housebill/2817/text?q=\%7B\%22search\%22\%3A\%5B\%22preschool\%22\%5D \% 7D\&r=2\&s=1

Child Care for Working Families Act of 2019, H. R., 116th Cong. (2019). https://www.congress.gov/bill/116th-congress/housebill/1364/actions?q=\% 7B \%22search $\% 22 \% 3 \mathrm{~A} \% 5 \mathrm{~B} \% 22 \mathrm{Child}+$ care+for+working+families+act $\%$ $22 \% 5 \mathrm{D} \% 7 \mathrm{D} \& \mathrm{r}=1 \& \mathrm{~s}=1$ 
Child Care for Working Families Act S. 1360, t. C. (2021). https://www.congress.gov/bill/117th-congress/senatebill/1360?q=\%7B\%22search\%22\%3A\%5B\%22preschool\%22\%5D\%7D\&s=1\&r=1

Child Care Services Association. (2021). WAGE\$ FAQs. https://www.childcareservices.org/programs/wages/

Dockterman, E. (2021). These mothers wanted to care for their kids and keep their jobs. Now they're suing after being fired. Time, 197(9-10), 71-76. https://time.com/5942117/mothers-fired-lawsuit-covid-19/

Economic Policy Institute. (2016). The Cost of Childcare in (enter state). https://www.epi.org/child-care-costs-in-the-united-states/

Economic Policy Institute. (2019). The cost of child care in South Carolina. https://www.epi.org/child-care-costs-in-the-united-states/\#/SC. Retrieved October 8, 2019, from Economic Policy Institute https://www.epi.org/child-care-costs-in-the-united-states/\#/SC

Families USA, \& States News Service. (2014a). Alabama report: Working individuals in key economic sectors make up the largest group to benefit from Medicaid expansion [Press release].https://advance-lexis com.libproxy.clemson.edu/api/document?collection=news\&id=urn:contentItem:5CSW-T101JCBF-S1JN-00000-00\&context=1516831

Families USA, \& States News Service. (2014b). Pennsylvania Report: Working individuals in key economic sectors make up the largest group to benefit from Medicaid expansion [Press release]. https://advance-lexiscom.libproxy.clemson.edu/api/document?collection=news\&id=urn:contentItem:5CT7-8JB1JCBF-S3YN-00000-00\& context=1516831.

Families USA, \& States News Service. (2014c). Report: Working individuals in key economic sectors would be the largest group to gain Medicaid coverage [Press release]. https://advance-lexiscom.libproxy.clemson.edu/api/document?collection=news\&id=urn:contentItem:5C4S-90C1JCBF-S25C-00000-00\& context=1516831.

Families USA, \& States News Service. (2014d). Tennessee Report: Working Individuals in key economic sectors make up the largest group to benefit from Medicaid expansion [Press release]. https://advance-lexiscom.libproxy.clemson.edu/api/document?collection=news\&id=urn:contentItem:5CWB-YGJ1JCBF-S01K-00000-00\&context $=1516831$

Families USA, \& States News Service. (2014e). Virginia Report: Working individuals in key economic sectors make up the largest group who would gain coverage through Medicaid Expansion expanding Medicaid would provide access to quality, affordable health care for 360,000 Virginians job creation, economic growth are important benefits of Medicaid dollars to state [Press release]. https://advance-lexiscom.libproxy.clemson.edu/api/document?collection=news\&id=urn:contentItem:5CC8-Y441DYTH-G3V0-00000-00\&context=1516831.

Families USA, \& States News Service. (2015a). Arkansas study: Working individuals make up the largest group who benefit from Medicaid expansion [Press release]. https://advance-lexiscom.libproxy.clemson.edu/api/document?collection=news\&id=urn:contentItem:5H22-VC41DYTH-G0CC-00000-00\&context=1516831.

Families USA, \& States News Service. (2015b). Kansas report: Working individuals in key economic sectors make up the largest group to benefit from Medicaid expansion [Press release]. 
https://advance-lexis-

com.libproxy.clemson.edu/api/document?collection=news\&id=urn:contentItem:5FJ8-M8K1DYTH-G42T-00000-00\&context=1516831.

Families USA, \& States News Service. (2015c). Minnesota study: Working individuals make up the largest group who benefit from Medicaid expansion study estimates that 67 percent of those benefiting from Minnesota's Medicaid expansion are working adults in key economic sectors [Press release].

https://advance-lexiscom.libproxy.clemson.edu/api/document?collection=news\&id=urn:contentItem:5H25-97G1JCBF-S3TD-00000-00\& context=1516831.

Families USA, \& States News Service. (2015d). Ohio study: Working individuals make up the largest group who benefit from Medicaid expansion study estimates that 55 percent of those benefiting from Ohio's Medicaid expansion are working adults in key economic sectors [Press release] https://advance-lexiscom.libproxy.clemson.edu/api/document?collection=news\&id=urn:contentItem:5H0N-K2S1DYTH-G30C-00000-00\&context=1516831

Families USA, \& Targeted News Service. (2014). Wyoming report: Working individuals in key economic sectors make up the largest group to benefit from Medicaid expansion [Press release] https://advance-lexiscom.libproxy.clemson.edu/api/document?collection=news\&id=urn:contentItem:5DTM-HMR1JC11-14C0-00000-00\&context $=1516831$.

Families USA, \& Targeted News Service. (2015). Kentucky study: Working individuals make up the largest group who benefit from Medicaid expansion. https://advance-lexiscom.libproxy.clemson.edu/api/document?collection=news\&id=urn:contentItem:5H3T-XJ81JC11-12BM-00000-00\&context=1516831.

First Five Years Fund. (2019). About us: Bipartisan advocacy that gets results. https://www.ffyf.org/about-us/

First Five Years Fund. (2021). Child care \& development block grant (CCDBG). https://www.ffyf.org/issues/ccdbg/

Flint, S. S. (2014). Who loses when a state declines the Medicaid expansion? Health \& Social Work, 39(2), 69-72. doi:10.1093/hsw/hlu012

Florida Atlantic University Libraries. (2021). Guide to science information resources: Backward \& forward reference searching. https://libguides.fau.edu/science_resources/reference_searching

Floyd, J. (2019). SC did not expand Medicaid under Obamacare, but cost and enrollment are growing anyway. The Post and Courier. https://www.postandcourier.com/health/sc-did-not-expandmedicaid-under-obamacare-but-cost-and/article_6f15cb26-24a2-11e9-9167-2373028041bb.html

Friedman-Krauss, A. H., Barnett, W. S., Garver, K. A., Hodges, K. S., Weisenfeld, G. G., \& DiCrecchio, N. (2019). The state of preschool 2018. State preschool yearbook. http://nieer.org/wpcontent/uploads/2019/08/YB2018_Full-ReportR3wAppendices.pdf

Garfield, R., Rudowitz, R., \& Orgera, K. (2019). Understanding the intersection of Medicaid and work: What does the data say? https://www.kff.org/medicaid/issue-brief/understanding-the-intersectionof-medicaid-and-work-what-does-the-data-say/

Glasmeier, A. K. M. I. o. T. (2021). New living wage data for now available on the tool. https://livingwage.mit.edu/articles/61-new-living-wage-data-for-now-available-on-the-tool 
Gould, E., Austin, L. J. E., \& Whitebook, M. (2017). What does good child care reform look like? https://www.epi.org/publication/what-does-good-child-care-reform-look-like/

Hall, J. P., Shartzer, A., Kurth, N. K., \& Thomas, K. C. (2018). Medicaid Expansion as an Employment Incentive Program for People With Disabilities. American Journal of Public Health, 108(9), 12351237. doi:10.2105/AJPH.2018.304536

Health Reform: Beyond the Basics. (2019). Yearly Guidelines and Thresholds. http://www.healthreformbeyondthebasics.org/wpcontent/uploads/2017/11/REFERENCEGUIDE_Yearly-Guidelines-and-Thresholds_2019.pdf

Henry J. Kaiser Family Foundation. (2015, March 9, 2015). Medicaid Moving Forward. https://www.kff.org/health-reform/issue-brief/medicaid-moving-forward/

Hinton, E., Musumeci, M., Rudowitz, R., Antonisse, L., \& Hall, C. (2019). Section 1115 Medicaid demonstration waivers: The current landscape of approved and pending waivers.https://www.kff.org/medicaid/issue-brief/section-1115-medicaid-demonstrationwaivers-the-current-landscape-of-approved-and-pending-waivers/

Howes, C., Whitebook, M., \& Phillips, D. (1992). Teacher characteristics and effective teaching in child care: Findings from the National Child Care Staffing Study. Child and Youth Care Forum, 21, 399-414. doi:10.1007/BF00757371

Huetteman, E. (2021). Pandemic aid package includes relief from high premiums. https://khn.org/news/article/aca-subsidies-pandemic-aid-package-includes-relief-from-highpremiums/?utm_campaign=KHN\%3A\%20Daily\%20Health\%20Policy\%20Report\&utm_mediu $\mathrm{m}=$ email\&_hsmi $=114931174 \& \_h s e n c=p 2 A N q t z-$ 8gg1il1RMAInGNJxaqfOBbYjT19zxtew8IxJa1uhkq86nJ6NAM4JycgoBcmlATH74Ui7n3EioN WZxyB4WaMN1yaG5H_Q\&utm_content=114931174\&utm_source=hs_email

Institute for Child Success. (2019). Research and policy. https://www.instituteforchildsuccess.org

Institute of Medicine. (2012). The early childhood care and education workforce: Challenges and opportunities: a workshop report. Washington, D.C.: National Academies Press.

Institute of Medicine, \& National Research Council. (2015). Transforming the workforce for children birth through age 8: A unifying foundation. Washington, DC: The National Academies Press.

Jaspen, B. (2019). More red state Medicaid ballot campaigns emerge for 2020. https://www.forbes.com/sites/brucejapsen/2019/09/08/more-red-state-medicaid-ballotcampaigns-emerge-for-2020/\#5bf2fe2e5fa9

Kaiser Family Foundation. (2019a). Custom State Reports. https://tinyurl.com/25vv75sd

Kaiser Family Foundation. (2019b). Medicaid in South Carolina. http://files.kff.org/attachment/fact-sheet-medicaid-state-SC

Kaiser Family Foundation. (2019c, October 9, 2019). Medicaid waiver tracker: Approved and pending section 1115. https://www.kff.org/medicaid/issue-brief/medicaid-waiver-tracker-approved-andpending-section-1115-waivers-by-state/\#Map1

Kaiser Family Foundation. (2019d). State health facts. https://www.kff.org/other/state-indicator/pooradults/?currentTimeframe $=4 \&$ selectedRows $=\% 7 \mathrm{~B} \% 22$ states $\% 22: \% 7 \mathrm{~B} \% 22$ southcarolina\%22:\%7B\%7D\%7D\%7D\&sortModel=\%7B\%22colId\%22:\%22Location\%22,\%22sort\% 22:\%22asc $\% 22 \% 7 \mathrm{D}$

Kaiser Family Foundation. (2019e, September 20, 2019). Status of state Medicaid expansion decisions: Interactive map. https://www.kff.org/medicaid/issue-brief/status-of-state-medicaid-expansiondecisions-interactive-map/ 
Kaiser Family Foundation. (2021a). Health coverage \& uninsured. https://www.kff.org/statecategory/health-coverage-uninsured/health-insurance-status/

Kaiser Family Foundation. (2021b). Status of state action on the Medicaid Expansion Decision. https://www.kff.org/health-reform/state-indicator/state-activity-around-expanding-medicaidunder-the-affordable-careact/?currentTimeframe=0\&sortModel=\%7B\%22colId\%22:\%22Location\%22,\%22sort\%22:\%22a sc $\% 22 \% 7 \mathrm{D}$

Kashen, J., Glynn, S. J., \& Novello, A. (2020). How COVID-19 sent women's workforce progress backwards.

https://www.americanprogress.org/issues/women/reports/2020/10/30/492582/covid-19-sentwomens-workforce-progress-backward/

Kasich, J. R., \& Sears, B. R. (2018). 2018 Ohio Medicaid group VIII assessment: A follow-up to the 2016 Ohio Medicaid group VIII assessment. https://medicaid.ohio.gov/Portals/0/Resources/Reports/Annual/Group-VIII-Final-Report.pdf

Keith, K. (2021). Biden Executive Order to reopen HealthCare.gov, make other changes. https://www.healthaffairs.org/do/10.1377/hblog20210129.998616/full/

Kim, S. M., DeBonsis, M., \& Stein, J. (2021). Biden claims bipartisan win with deal on infrastructure. The Washington Post. https://www.washingtonpost.com/politics/bipartisan-group-of-senators-to-meet-with-biden-atwhite-house-to-try-to-finalize-infrastructure-deal/2021/06/24/6710e90c-d4e9-11eb-ae54$515 \mathrm{e} 2 \mathrm{f} 63 \mathrm{~d} 37 \mathrm{~d} \_$story.html

Kwon, K.-A. (2019). Are early childhood teachers happy and healthy? This research study will find out. https://www.edsurge.com/news/2019-10-09-are-early-childhood-teachers-happy-and-healthythis-research-study-will-find-out

Leach, M. (2021, February 9, 2021). [Health Care Access for Child Care Workers].

Leavitt Partners. (2013). Covering the low-income, uninsured in Oklahoma. https://www.google.com/url?sa=t\&rct=j\&q=\&esrc=s\&source=web\&cd=1\&ved=2ahUKEwiDgq aL7571AhVHAqwKHc4YD14QFjAAegQIAxAC\&url=https\%3A\%2F\%2Fwww.okhca.org\%2F WorkArea\%2FDownloadAsset.aspx\%3Fid\%3D14953\&usg=AOvVaw12ZpZm8aV6PBjMnsTi5 $8 \mathrm{q}-$

Lee, D.-C., Shi, L., \& Liang, H. (2018). Primary care utilization and clinical quality performance: a comparison between health centres in Medicaid expansion states and non-expansion states. Journal of Health Services Research \& Policy, 24(1), 19-28. doi:10.1177/1355819618788592

Linnan, L., Arandia, G., Bateman, L. A., Vaughn, A., Smith, N., \& Ward, D. (2017). The health and working conditions of women employed in child care. International Journal of Environmental Research and Public Health, 14(3). doi:10.3390/ijerph14030283

Mahan, D., Families USA, \& States News Service. (2014). Medicaid expansion would primarily help uninsured workers [Press release].

https://advance-lexis-

com.libproxy.clemson.edu/api/document?collection=news\&id=urn:contentItem:5CHM-T821JCBF-S48C-00000-00\&context=1516831

Malik, R. (2019). Working families are spending big money on child care. https://www.americanprogress.org/issues/early-childhood/reports/2019/06/20/471141/workingfamilies-spending-big-money-child-care/

Manchikanti, L., Helm Ii, S., Benyamin, R. M., \& Hirsch, J. A. (2017). A critical analysis of Obamacare: Affordable care or insurance for many and coverage for few? Pain Physician, 20(3), 111-138. 
McDougald Scott, A. M. (2018). Child care: an economic imperative for Greenville. https://www.instituteforchildsuccess.org/child-care-an-economic-imperative-for-greenville/

McDougald Scott, A. M. (2021a). Examining the Everyday Life of Child Care Workers: How Low Wages and the Lack of Benefits Affect Daily Life, Decisions about Employment, and What They Need You to Know (Unpublished doctoral dissertation): Clemson University, Clemson, South Carolina.

McDougald Scott, A. M. (2021b, June 25, 2021). Examining the Everyday Life of Child Care Workers: How Low Wages and the Lack of Benefits Affect their Lives and Decisions about Employment. Paper presented at the Society for Community Research and Action Biennial: Uprooting White Supremacy, Zoom.

McDougald Scott, A. M., Rusnak, S., \& Carolan, M. (2019). South Carolina early childhood data report. https://www.instituteforchildsuccess.org/publication/2019-sc-databook/

McLean, C., Austin, L. J. E., Whitebook, M., \& Olson, K. L. (2021). Early childhood workforce index 2020. https://cscce.berkeley.edu/workforce-index-2020/report-pdf/

McMorrow, S., Kenney, G. M., Long, S. K., \& Goin, D. E. (2016). Medicaid expansions from 1997 to 2009 increased coverage and improved access and mental health outcomes for low-income parents. Health Services Research, 51(4), 1347-1367. doi:10.1111/1475-6773.12432

Michael in Norfolk. (2018). 43\% of American households struggling to afford basic middle class life. https://advance-lexiscom.libproxy.clemson.edu/api/document?collection=news\&id=urn:contentItem:5SBV-CJW1F03R-N3VG-00000-00\&context=1516831.

Michel, S. (1999). Children's Interests/mothers' Rights : The Shaping of America's Child Care Policy. New Haven, Conn: Yale University Press.

National Association for the Education of Young Children (NAEYC). (2019). Become an advocate. https://www.naeyc.org/get-involved/advocate

National Center on Early Childhood Quality Assurance. (2015). Increasing quality in early care and education programs: Effects on expenses and revenues. https://childcareta.acf.hhs.gov/sites/default/files/public/pcqc_increase_quality_final.pdf

National Conference of State Legislatures. (2012, September 20, 2012). Initiative, referendum and recall. https://www.ncsl.org/research/elections-and-campaigns/initiative-referendum-and-recalloverview.aspx

National Survey of Early Care and Education Project Team. (2020). 2019 National Survey of Early Care and Education (NSECE) Preliminary 2019 Workforce data-file and documentation. https://www.norc.org/Research/Projects/Pages/national-survey-of-early-care-and-education.aspx

National Survey of Early Care and Education Project Team (National Opinion Research Center). (2012). National Survey of Early Care and Education (NSECE), United States, 2010-2012. https://www.researchconnections.org/childcare/studies/35519

New America. (2019). Our work. https://www.newamerica.org/our-story/

O’Donnell, K. (2015). Financing early care and education: Options for South Carolina. https://www.instituteforchildsuccess.org/publication/financing-early-care-education-optionssouth-carolina/

Office of Child Care, Administration for Children \& Families, U.S. Department of Health \& Human Services. (2019, June 24, 2019). Child care and development fund reauthorization. https://www.acf.hhs.gov/occ/ccdf-reauthorization

Oklahoma Health Care Authority. (2005). A history in brief...Oklahoma Health Care Authority. http://www.okhca.org/publications/pdflib/PR_brief05.pdf 
Oklahoma Health Care Authority. (2013). 1115(a) SoonerCare Research and Demonstration Waiver Amendment Request, Project Number: 11-W-00048/6. https://www.medicaid.gov/Medicaid-CHIP-Program-Information/ByTopics/Waivers/1115/downloads/ok/SoonerCare/ok-soonercare-research-demo-waiver.pdf

Oklahoma Health Care Authority. (2018a). Oklahoma Health Care Authority SoonerCare1115(a) Research and Demonstration Waiver Amendment Request Project Number 11-W-00048/6. https://www.medicaid.gov/Medicaid-CHIP-Program-Information/ByTopics/Waivers/1115/downloads/ok/ok-soonercare-pa6.pdf

Oklahoma Health Care Authority. (2018b). Soonercare 1115(a) Research and Demonstration Waiver Amendment Request Project No. 11-W-0048/6.

https://www.google.com/url?sa=t\&rct=j\&q=\&esrc=s\&source=web\&cd=1\&ved=2ahUKEwj91M e41pzlAhXuc98KHdO-

CGcQFjAAegQIABAC\&url=https\%3A\%2F\%2Fokhca.org\%2FWorkArea\%2FDownloadAsset.a spx\%3Fid\%3D22247\&usg=AOvVaw3_11XKlyFN999GELPG8rrk

Oklahoma Health Care Authority. (2019). Insure Oklahoma, what is the Individual Plan? http://www.insureoklahoma.org/IOindividuals.aspx?id=3896

Otten, J. J., Bradford, V. A., Stover, B., Dill, H. D., Osborne, C., Getts, K., \& Seixas, N. (2019). The culture of health in early care And education: Workers' wages, health, And job characteristics. Health Affairs, 38(5), 709-720. doi:10.1377/hlthaff.2018.05493

Paschall, K. (2019). Nearly 30 percent of infants and toddlers attend home-base child care as their primary arrangement. https://www.childtrends.org/nearly-30-percent-of-infants-and-toddlersattend-home-based-child-care-as-their-primary-arrangement

Pettus, E. W., \& Associated Press State \& Local Wire. (2013). Miss. panel hears about uninsured working poor. [Press release].

https://advance-lexis-

com.libproxy.clemson.edu/api/document?collection=news\&id=urn:contentItem:57SV-YNV1DXYN-514N-00000-00\&context $=1516831$

Pope, E. C. (2013). Medicaid expansion will save Colorado more than $\$ 280$ million over 10 years. https://advance-lexiscom.libproxy.clemson.edu/api/document?collection=news\&id=urn:contentItem:57HG-4VS1F03R-N3KW-00000-00\&context=1516831.

Pore, R. (2012, August 26, 2012, Sunday). More Medicaid makes sense for; people, budget. Charleston Gazette (West Virginia).

https://advance-lexis-

com.libproxy.clemson.edu/api/document?collection=news\&id=urn:contentItem:56F6-GKH1JCB7-1338-00000-00\& context=1516831.

Potempa, A. (2002, May 28, 2002 Tuesday). A Smaller Vision; Sweeping health-care reforms went nowhere, but Alaska is now finding success with scaled-down projects.

https://advance-lexis-

com.libproxy.clemson.edu/api/document?collection=news\&id=urn:contentItem:4N2F-G1J0TX4T-B3F6-00000-00\&context=1516831

RAND Corporation. (2019a). The Affordable Care Act. https://www.rand.org/health-care/keytopics/health-policy/aca.html

RAND Corporation. (2019b). The Affordable Care Act in depth. https://www.rand.org/health-care/keytopics/health-policy/aca/in-depth.html

Rao, V., \& Chen, R. (2018). Early childhood workforce study report - 2018 
https://sc.edu/study/colleges_schools/education/research/cdrc/scworkforcestudy2018.pdf

Robert Wood Johnson Foundation. (2019). Medicaid's impact on health care access, outcomes, and state economies.

https://www.rwjf.org/en/library/research/2019/02/medicaid-s-impact-on-health-care-accessoutcomes-and-state-economies.html

Robertson, G. D. (2019). As impasse continues, speaker won't stop override effort [Press release]. https://advance-lexiscom.libproxy.clemson.edu/api/document?collection=news\&id=urn:contentItem:5WS9-Y7S1DYN6-W45D-00000-00\&context=1516831

Rudowitz, R., \& Antonisse, L. (2018). Implications of the ACA Medicaid Expansion: A Look at the Data and Evidence. Kaiser Family Foundation. Retrieved from https://www.kff.org/medicaid/issuebrief/implications-of-the-aca-medicaid-expansion-a-look-at-the-data-and-evidence/

Russell, S. D., Lyons, J. D., \& Lowman, B. C. (2001). The early childhood system in Greenville, availability, quality, and affordability of child care in the year 2001. Retrieved from Chapel Hill, NC:

Sausser, L. (2017). Will South Carolina expand Medicaid? Gov. Henry McMaster's administration says no. The Post and Courier.

https://www.postandcourier.com/health/will-south-carolina-expand-medicaid-gov-henrymcmaster-s-administration/article_8c72c21e-c8af-11e7-906f-c33a0c362501.html

Schlieber, M., Whitebook, M., Austin, L. J. E., \& Hankey, A., Duke, M. (2019). Teacher's voices: Work environment conditions that impact teacher practice and program quality-Marin County. https://cscce.berkeley.edu/files/2019/12/SEQUAL-Marin-FINAL.pdf

Schochet, L. (2019). The child care crisis is keeping women out of the workforce. https://www.americanprogress.org/issues/early-childhood/reports/2019/03/28/467488/child-carecrisis-keeping-women-workforce/

Senate Finance, Donna Cohen Ross, Director of Outreach. (March 15, 2001, Thursday). Testimony Living Without Health Insurance. Federal Document Clearing House Congressional Testimony. https://advance-lexiscom.libproxy.clemson.edu/api/document?collection=news\&id=urn:contentItem:42KC-R7K00003-1003-00000-00\& context=1516831.

Shartzer, A., Blavin, F., \& Holahan, J. (2018). Employer-sponsored insurance stable for low-income workers in medicaid expansion states. Health Affairs, 37(4), 607-612A-612J. http://dx.doi.org.libproxy.clemson.edu/10.1377/hlthaff.2017.1205

Smith, P. R. (2004). Caring for Paid Caregivers: Linking Quality Child Care with Improved Working Conditions Symposium: Women's Work Is Never Done: Employment, Family, and Activism. University of Cincinnati Law Review, 73(2), 399-432

https://heinonline.org/HOL/PrintRequest?handle=hein.journals/ucinlr73\&collection=journals\&di $\mathrm{v}=22 \& \mathrm{id}=411 \&$ print $=$ section \&sction $=22$

Sommers, B. D., Maylone, B., Blendon, R. J., Orav, E. J., \& Epstein, A. M. (2017). Three-year impacts of the Affordable Care Act: Improved medical care and health among low-income adults. Health Affairs, 36(6), 1119-1128. doi:10.1377/hlthaff.2017.0293

South Carolina Center for Child Care Career Development. (2019a). South Carolina's Early Care and Education Credentialing System. http://www.sc-ccccd.net/Credentialing/Credentialing.html

South Carolina Center for Child Care Career Development. (2019b). T.E.A.C.H. Early Childhood Scholarship Program. http://www.sc-ccccd.net/TEACH/TEACH.html 
South Carolina Healthy Connections Medicaid. (2014). Modified Adjusted Gross Income (MAGI)-based eligibility groups, The Affordable Care Act (ACA): January 1, 2014 changes to Medicaid eligibility determination. https://www.scdhhs.gov/magi

South Carolina Healthy Connections Medicaid. (2019). Getting started. https://www.scdhhs.gov/Getting-Started\#coveragegroups

Stewart, K. (2014, May 21, 2014 Wednesday). Utahns in the 'Medicaid gap' are working; here's where. . The Salt Lake Tribune. https://advance-lexiscom.libproxy.clemson.edu/api/document?collection=news\&id=urn:contentItem:5C86-CCG1DYT4-V3XC-00000-00\&context=1516831.

T.E.A.C.H. Early Childhood National Center. (2019a). Child Care WAGE\$. https://teachecnationalcenter.org/child-care-wage/

T.E.A.C.H. Early Childhood National Center. (2019b). T.E.A.C.H. state contacts. https://teachecnationalcenter.org/state-contacts/

Teacher.org. (2019). How to become a Kindergarten teacher. https://www.teacher.org/career/kindergarten-teacher/

The Hatcher Group. (2019). Taking action: Positioning low-income workers to succeed in a changing economy. https://www.aecf.org/resources/taking-action/

The White House. (2021). Fact Sheet: The American Families Plan. https://www.whitehouse.gov/briefing-room/statements-releases/2021/04/28/fact-sheet-theamerican-families-plan/

Thomason, M. (2019, October 17, 2019). [Clarification on gaps in Oklahoma Health Care Authority research].

Thomason, S., Austin, L. J. E., Bernhardt, A., Dresser, L., Jacobs, K., \& Whitebook, M. (2018). At the wage floor. https://cscce.berkeley.edu/at-the-wage-floor/

Tipirneni, R., Kullgren, J. T., Ayanian, J. Z., Kieffer, E. C., Rosland, A.-M., Chang, T., . . Goold, S. D. (2019). Changes in health and ability to work among Medicaid expansion enrollees: a mixed methods study. Journal of General Internal Medicine, 34(2), 272-280. doi:10.1007/s11606-0184736-8

U.S. Department of Health \& Human Services. (2019a, September 30, 2019). About the Affordable Care Act. https://www.hhs.gov/healthcare/about-the-aca/index.html

U.S. Department of Health \& Human Services. (2019b, February 1, 2019). HHS poverty guidelines for 2019. https://aspe.hhs.gov/poverty-guidelines

U.S. Department of Health \& Human Services. (2021). 2021 Percentage Poverty Tool. https://aspe.hhs.gov/poverty-guidelines?cid=7385d86791383a0c2e8b841b1476ed65

USC Institute for Families in Society, University of South Carolina. (2018). Medicaid enrollment, full benefits members for all counties. http://www.schealthviz.sc.edu/medicaid-enrollment

Whitaker, R. C., Becker, B. D., Herman, A. N., \& Gooze, R. A. (2013). The physical and mental health of Head Start staff: the Pennsylvania Head Start staff wellness survey, 2012. Prev Chronic Dis, 10, E181. doi:10.5888/pcd10.130171

Whitebook, M., McLean, C., Austin, L. J. E., \& Edwards, B. (2018). Early Childhood Workforce Index2018. http://cscce.berkeley.edu/topic/early-childhood-work-force-index/2018/

Whitebook, M., Phillips, D., \& Howes, C. (2014). Worthy work, STILL unlivable wages: the early childhood workforce 25 years after the National Child Care Staffing Study. https://cscce.berkeley.edu/files/2014/ReportFINAL.pdf 
Whitebook, M., \& Sakai, L. (2003). Turnover begets turnover: An examination of job and occupational instability among child care center staff. Early Childhood Research Quarterly, 18(3), 273-293. https://cscce.berkeley.edu/files/2003/turnoverchildcare.pdf

Zhao, T., Xu, Y., \& He, Y. (2019). Graph theoretical modeling of baby brain networks. NeuroImage, 185, 711-727. doi:10.1016/j.neuroimage.2018.06.038 